FIU Law Review

Fall 2012

\title{
Paradigm Shifts \& Unintended Consequences: The Death of the Specialist, the Rise of High Frequency Trading, \& the Problem of Duty-Free Liquidity in Equity Markets
}

Jennifer Victoria Christine Dean

Follow this and additional works at: https://ecollections.law.fiu.edu/lawreview

Part of the Other Law Commons

Online ISSN: 2643-7759

Recommended Citation

Jennifer V. Dean, Paradigm Shifts \& Unintended Consequences: The Death of the Specialist, the Rise of High Frequency Trading, \& the Problem of Duty-Free Liquidity in Equity Markets, 8 FIU L. Rev. 217 (2012).

DOI: https://dx.doi.org/10.25148/lawrev.8.1.15

This Article is brought to you for free and open access by eCollections. It has been accepted for inclusion in FIU Law Review by an authorized editor of eCollections. For more information, please contact lisdavis@fiu.edu. 


\title{
Paradigm Shifts \& Unintended Consequences: The Death of the Specialist, the Rise of High Frequency Trading, \& the Problem of Duty-Free Liquidity in Equity Markets
}

\author{
Jennifer Victoria Christine Dean*
}

\section{INTRODUCTION}

Every business day, hundreds of thousands of people turn on their televisions to watch CNBC. ${ }^{1}$ Millions more tune in to listen to Bloomberg radio. ${ }^{2}$ Thousands of men and women get home from work and open brokerage statements received in the day's mail. These people have one thing in common: they want to know what is happening with the money. The stock market is more than just a place where people buy and sell stocks; the health of the stock market (more specifically the health of the stock marketplace) is both an indicator of, and a substantial factor in, the health of the worldwide economy. ${ }^{3}$ The stock market is more than just some abstraction on the news; it is to financial capitalism what the circulatory system is to the

* Jennifer Victoria Christine Dean, J.D., Florida International University College of Law, 2012; B.A., New York University, Gallatin School of Individualized Study, 2002; M.N.M., Florida Atlantic University, 2009. I would very much like to thank the following people for supporting me, and for challenging me to be a better thinker and scholar. Thank you to Professor Christyno Hayes, Dean Jose Gabilondo, Professor Jerry Markham, Professor David Walter, Scott Mcpartland-and most of all, my father.

1 Brian Stelter, Market Ills Give CNBC a Bounce, N.Y. TIMES (Aug. 14, 2011), http://www.nytimes.com/2011/08/15/business/media/market-gyrations-aid-cnbc-in-battle-for viewers.html?pagewanted=all.

2 Bloomberg Television Audience Is Cable's Wealthiest, New Mendelsohn Affluent Survey Reveals, PR NEWSWIRE (Oct. 28, 2004), http://www.prnewswire.com/news-releases/bloombergtelevision-audience-is-cables-wealthiest-new-mendelsohn-affluent-survey-reveals72746037.html.

3 See Stock Market Performance, EconomyWATCH.com (Nov. 23, 2010), http://www.economywatch.com/stock-markets-in-world/performance.html; see also Wen Mao \& Michael S. Pagano, Specialists as Risk Managers: The Competition Between Intermediated and Non-intermediated Markets, 35 J. BANKING \& FIN. 51, 51-52 (2011); Therese H. Maynard, What Is an "Exchange?"-Proprietary Electronic Securities Trading Systems and the Statutory Definition of an Exchange, 49 WASH. \& LEE L. REV. 833, 840 (1992) ("[t]he economic function of the trading markets is to create liquidity ...”). 
human body. The stock market moves information. It moves money, and it allows people to take the pulse of the economy.

For more than a hundred years, from the 1870s (when the first telephone was installed on the fabled "Floor" of the NYSE), to the beginning of the twenty-first century (when computers took over the vast majority of trading volume), a small group of specially qualified human beings helped control the flow of stock trading. In doing so, they maintained the ability to protect both consumers and the economy at large from potentially dangerous swings in market volatility. These men, who maintained market liquidity, guided the flow of trades, matched orders, and generally helped maintain a fair and orderly market, were members of a category of market participant called "market-makers." At the New York Stock Exchange ("NYSE"), these stewards held the title "specialist."

Today, NYSE specialists (and their counterparts at other exchanges) no longer exist. ' A perfect storm of regulatory and policy changes (which came to a head in the mid to late 1990s), combined with the advent of ever faster technology and structural market changes, led to the disappearance of exchange specialists. ${ }^{10}$ This article is, in part, about the consequences of their disappearance. It is also about the market liquidity function that exchange specialists once

4 U.S. CONG., OfFICE of TECh. Assessment, OTA-CIT-469, EleCtronic Bulls AND BEARS: U.S. SECURITIES MARKETS AND INFORMATION TECHNOLOGY, 129 (1990) [hereinafter ELECTRONIC BULLS AND BEARS], available at http://www.fas.org/ota/reports/9015.pdf (acknowledging that the first successful telephone call was placed by Alexander Graham Bell in 1876); THE New York Stock Exchange: The First 200 YeArs 49 (James E. Buck ed. 1992) (describing the NYSE's pioneering use of the telephone).

5 See Tara Bhupathi, Technology's Latest Market Manipulator? High Frequency Trading: The Strategies, Tools, Risks, and Responses, 11 N.C.J.L.\& TECH.377,381 (2010).

6 See generally Marios A. Panayides, Affirmative Obligations and Market-making with Inventory, 86 J. FIN. ECON. 513 (2007), available at http://www.pitt.edu/ mariosp/ AffirmativeObligations.pdf ("shed[ding] light on how exchange rules affect market-makers' behavior and market quality").

7 See Kumar Venkataraman \& Andrew C. Waisburd, The Value of the Designated Market Maker, 42(3) J. FIN. \& QUANTITATIVE ANALYSIS 735, 735-36 (2007), available at http://kvenkataraman.cox.smu.edu/papers/VW.pdf.

8 Joel Hasbrouck \& George Sofianos, The Trade of Market Makers: An Empirical Analysis of NYSE Specialists, 48 J. FIN. 1565, 1568 (1993); Peter Chapman, 2008 Review: NYSE Fights Back with Designated Market-Makers, TRADER'S MAG. (Dec. 2008), http://www. tradersmagazine.com/issues/20_289/102770-1.html (explaining that in 2008, in response to the changing structure of equity markets, the NYSE renamed the specialists "Designated Marketmakers" and moved their place of business from the floor of the NYSE to the upstairs offices).

9 See Chapman, supra note 8. In January 2010, "La Branche \& Co., the largest Specialist firm in 2008, exited the business saying it would seek higher profits elsewhere." Nina Mehta, SEC Questions Trading Crusade as Market-Makers Disappear, BLOOMBERG.COM (Sept. 13, 2010, 7:01 PM), http://www.bloomberg.com/news/2010-09-13/sec-second-guesses-its-stock-trading-crusadeas-u-s-market-makers-vanish.html.

10 See Chapman, supra note 8. 
provided, and how current regulatory policy has left U.S. equity markets without enough obligated meaningful liquidity providers.

Specialists were not perfect. They certainly made mistakes, and history books are littered with occasions where they fell prey to human temptation, but the specialists had one valuable quality that computers do not have-they could be accountable."

For most of its history, the securities industry was necessarily selfregulating. ${ }^{12}$ The market for equity trading in the United States first began in the early eighteenth century. ${ }^{13}$ However, because the Securities and Exchange Commission ("SEC") was not created until 1934, for most of U.S. equity market history, the burden of regulating the securities industry fell to the institutions where trading took placeinstitutions like the NYSE. ${ }^{14}$ Over time, the NYSE (and institutions like it) developed rules and regulations that governed the behavior of its members. ${ }^{15}$ There were rules and regulations governing most aspects of trading, ${ }^{16}$ but because of the central role that specialists played in the marketplace, particular attention was paid to the rules and regulations governing their behavior. ${ }^{17}$ The rules that eventually emerged (rules addressing affirmative and negative obligations of the specialists, and the specialists' obligation to ensure equity market liquidity) are a large part of the foundation of this article.

11 See In re NYSE Specialists Sec. Litig., 503 F.3d 89, 92 (2d Cir. 2007); see also George T. Simon \& Kathryn M. Trkla, The Regulation of Specialists and Implications for the Future, 61 BUS. LAW. 217, 230 (2005); see generally SEC. \& EXCH. COMM'N, REPORT OF SPECIAL STUDY OF THE SECURITIES MARKeTS OF THE SECURITIES AND EXCHANGE COMMISSION, H.R. Doc No. 95, pt. 2, at 61 (1963) (Report to House Committee on Interstate and Foreign Commerce) [hereinafter "Special Study"] (The Special Study was a nearly 900 page document commissioned in response to suspected impropriety on the part of exchanges.).

12 See generally Paul G. Mahoney, The Exchange As Regulator, 83 VA. L. REV. 1453, 1457 (1997) (explaining that at the time that the NYSE was created, the only real industry regulation came from the trading institutions.); see also Mark Borrelli, Market-Making in the Electronic Age, 32 LOY. U. CHI. L.J. 815, 820 (2001) ("Historically the NYSE was considered the most prestigious and liquid market in existence..."). As a result, from the second half of the nineteenth century to the 1930s [and the creation of the Securities and Exchanges Commission] the NYSE Byelaws were the most powerful and influential regulations in the world when it came to governing the behavior of equity market participants. See also Ken Sweet, NYSE's Grab at a \$3.7 Quadrillion Market, CNNMONEY (Feb. 14, 2011, 2:26 PM), http://money.cnn.com/2011/02/14/ markets/nyse_banks/index.htm (noting that even after the creation of the SEC, the NYSE's regulation department continued to act as the leader in the field).

131 Jerry W. Markham, A Financial History of the United States: From CHRISTOPHER COLUMBUS TO THE ROBBER BARRONS (1492-1900) 116-118 (2001) [hereinafter MARKHAM, COLUMBUS].

14 See Simon \& Trkla, supra note 11, at 246.

15 See Jerry W. Markham \& Daniel J. Harty, For Whom the Bell Tolls: The Demise of Exchange Trading Floors and the Growth of ECNs, 33 J. CORP. L. 865, 885 (2008).

16 See id. at 881.

17 See Simon \& Trkla, supra note 11, at 224. 
The specialists and the exchange-based rules that governed their behavior (primarily affirmative and negative obligations) were regulatory tools that were used to protect the industry from the dangers of volatility and market illiquidity. ${ }^{18}$ By placing limitations and obligations on the actions of a few central players (namely, the specialists), the exchanges (and by proxy, the SEC) could ensure market liquidity in times of crisis, thereby decreasing volatility and helping to maintain a fair and orderly market-one of the SEC's primary objectives. Specialists were market-makers who stood ready, willing and obligated to buy or sell a stock when there was little or no open market demand for a given stock. ${ }^{19}$ These specialized market-makers were subject to strict rules and regulations; if a specialist did not fulfill his obligations, he got fired. ${ }^{20}$ Because the majority of equity trading volume was traded through the NYSE, ${ }^{21}$ and because there were a limited number of NYSE memberships available, ${ }^{22}$ there was sufficient market pressure to ensure that the market as a whole was both subject to, and a beneficiary of the system.

Over the course of two hundred years, the largely exchangebased system for ensuring market liquidity adapted and grew as needed, but as the end of the twentieth century neared, new technology (and corresponding regulatory and policy changes) shifted the mechanics of the marketplace in a way that would reach long and far. With new technology at the ready and congressional policies that supported increased competition in place, a large percentage of equity trading volume migrated from exchanges to alternative trading systems. ${ }^{24}$ At roughly the same time (for different, but related reasons)

18 Id.

19 Id. at 222.

20 See generally Amber Anand et al., Cleaning House: Stock Reassignments on the NYSE (Syracuse Univ. \& Purdue Univ, Working Paper, 2007), available at http://www.cfs. purdue.edu/csr/research/Chakravarty-research/NYSE\%20specialist\%20reassignment.pdf (explaining the NYSE's policy of reassigning stocks to other specialist firms).

21 Div. of Mkt. Regulation, U.S. Sec. And ExCh. COMM'N, Market 2000: An EXAMINATION OF CURRENT EQUITY MARKET DEVELOPMENTS 8 (1994) [hereinafter MARKET 2000], available at http://www.sec.gov/divisions/marketreg/market2000.pdf; ELECTRONIC BULLS AND BEARS, supra note 4, at 7 (indicating that as of 1990, the "NYSE [did] almost 95\% of trading in exchange-listed stocks").

22 See infra notes 70-81 and accompanying text; Press Release, New York Stock Exchange, New York Stock Exchange Ends Member Seat Sales Today (Dec. 30, 2004), available at http://www.nyse.com/press/1135856420824.html [hereinafter Press Release] (describing the evolution of NYSE memberships).

23 See Borrelli, supra note 12, at 827.

24 See Concept Release on Equity Market Structure, Exchange Act Release No. 34-61358; 75 Fed. Reg. 3594, 3597 (Jan. 21, 2010) [hereinafter "Equity Market Structure Concept Release"] (requesting comments on the current state of equity market micro-structure); see ELECTRONIC BULLS AND BEARS, supra note 4, at 7 (While in 1990, the NYSE was responsible for executing 
the specialists were forced out of business, ${ }^{25}$ and with the specialists out of business, the specialist-based system of liquidity provision disappeared with them. In its place, a new system for providing liquidity emerged-a system rooted in the ideals of the new paradigm of automated trading systems.

The problem with this new system is that the old rules-the rules that once governed exchange-based trading-are no longer relevant. The old rules are inadequate to safeguard against the dangers associated with market illiquidity. Consequently, the current state of the market is thus: high-frequency traders and other new market liquidity providers (who have taken the place formerly occupied by exchange specialists and their brethren) have no obligation to provide market liquidity. The new system holds no one accountable.

This transfer of power has left a regulatory gap in its wake. The paradigm shift from exchange-based trading to alternative trading systems has created a loophole, which allows market participants to hold themselves out as market liquidity providers without any kind of accountability attaching to their actions. This paper takes the point of view that high-frequency traders, and other market participants of size, who hold themselves out as market liquidity providers, should be subject to mandatory market-making obligations.

This article begins with a snapshot of the current landscape of trading liquidity problems. Next, a brief history of the rules and regulations guiding and governing U.S. equity markets is presentedfollowed by an explanation of market-making, market liquidity, and the evolution of the role of market liquidity providers. The penultimate section will discuss specialists, high-frequency traders, and the paradigm shift that led to the change in liquidity provision mechanisms. The article will finish by offering potential avenues of change that if implemented will help curtail the unintended and dangerous consequences created by changes in equity market structure present since the implementation of the national market system mandate.

ninety-five percent of the volume of nationally listed stocks, by October 2009, the NYSE handled just over $25 \%$ of its own listed stocks); U.S. CENSUS BUREAU, STATISTICAL ABSTRACT OF THE United STATES: 2011, 750 (2011) (see Table 1208. Transaction Activity in Equities, Options, and Security Futures, 1990 to 2009, and by Exchange, 2009), available at http://www.census.gov/compendia/statab/2011/tables/11s1209.pdf (demonstrating that by 2009, the New York Stock Exchange handled just over 7 of the market for nationally traded stocks).

25 See Nina Mehta, SEC Questions Trading Crusade as Market-Makers Disappear, BLOOMBERG.COM (Sept. 13, 2010, 7:01 PM), http://www.bloomberg.com/news/2010-09-13/secsecond-guesses-its-stock-trading-crusade-as-u-s-market-makers-vanish.html. 


\section{EQUiTy MARKET LIQUIDITY:THE CURRENT STATE OF MARKET LIQUIDITY PROVIDERS}

The rise of electronic communication networks and highfrequency trading has changed both the composition of the equity marketplace and the way that the marketplace functions. The 1973 congressionally mandated creation of a national market system, along with the chosen path of regulation for automated order matching systems, has had the unintended consequence of forcing stock exchanges (the longstanding first line of defense in consumer protection) into a supporting role.

As both trading volume and regulatory control have drifted away from the NYSE (and other exchanges), the reign of the specialist has ended. In its place, a new type of market participant has emerged as victor. This new reigning champion of Wall Street is the highfrequency trader. ${ }^{27}$ During the last quarter of the twentieth century, various regulations and congressional actions (generally designed to help create more efficient markets through competition and transparency) came together and gave birth to a new breed of equity trading venue. $^{28}$ These new venues (alternately referred to as alternative trading systems, automated trading systems, electronic communications networks, and proprietary trading systems), in turn, gave rise to highfrequency trading. ${ }^{29}$ Computers have changed nearly every aspect of our world, and the stock market is certainly no exception. ${ }^{30}$ Where once upon a time stocks were traded in a physical marketplace and routed through brokers - human beings with a pulse-with the rise of alternative trading systems (and more specifically high-frequency trading), the trading volume that once flowed through the exchanges has been re-routed to these new order-matching venues. ${ }^{31}$ By some accounts, up to seventy percent of all equity trades are now executed through high-frequency trading programs.

26 See id.

27 Jonathan Spicer \& Herbert Lash, Who's Afraid of High-frequency Trading?, THOMSON REUTERS (Dec. 2, 2009, 10:38 AM), http://www.reuters.com/article/2009/12/02/us-highfrequencyidUSN173583920091202.

28 Liz Moyer \& Emily Lambert, The New Masters of Wall Street, ForBES.COM (Sept. 2, 2009, 6:00 PM), http://www.forbes.com/forbes/2009/0921/revolutionaries-stocks-getco-newmasters-of-wall-street.html.

29 Michael Durbin, All About High-Frequency Trading 6-7 (2010).

30 See Jonathan R. Macey \& Maureen O'Hara, From Markets to Venues: Securities Regulation in an Evolving World, 58 STAN. L. REV. 563, 565 (2005); Thomas W. Malone et al., Electronic Markets and Electronic Hierarchies, 30 COMM. ACM 484 (2007).

31 Mehta, supra note 25.

32 Moyer \& Lambert, supra note 28; DURBIN, supra note 29. 
High-frequency trading is conducted at a blindingly fast pace. ${ }^{33}$ Trades are executed in increasingly smaller fractions of a second. Huge volume is transacted, and almost none of it is initiated by human beings-except insofar as a human being is needed to execute a run command for the computer's trading algorithm. ${ }^{35}$ The emergence of the high-frequency trader is the direct result of the proliferation of alternative trading systems. These hybrid trading systems are alternative venues for the purchase and sale of stock; they are venues that are by design, not classified as "exchanges" by the SEC. ${ }^{36}$ In order to be able to register with the SEC as a "national exchange," a trading venue must meet extremely high standards, including the ability to self-regulate. ${ }^{37}$ The standards for participating in the equity marketplace as an alternative trading system do not include this requirement. ${ }^{38}$ As alternative-trading systems entered the market and began competing for (and successfully capturing) ever-larger percentages of the trading volume, a serious problem emerged.

For most of trading history, human beings (acting in the role of market-makers) have served as market liquidity providers. This is no longer the case. As blindingly fast technology and computer algorithms have acquired an increasingly large percentage of equity trading volume, the liquidity provision post that specialists once occupied, has been left vacant. If this were where the story ended, it would be yet another sad tale of a class of workers being made obsolete by technology-but this is not where the story ends. The NYSE specialists were not just men doing their jobs; they served a crucial function in the maintenance of a healthy financial marketplace. ${ }^{39}$ As the specialists were forced out of the business of market-making; they were resultantly also forced out of their role as the U.S. equity markets' primary trading liquidity providers. Their role as market liquidity

33 Moyer \& Lambert, supra note 28.

34 Equity Market Structure Concept Release, supra note 24, at 3595; see also Graham Bowley, The New Speed of Money, Reshaping Markets, N.Y. TIMES (Jan. 1, 2011) ("Fear of this volatile, blindingly fast market may be why ordinary investors have been withdrawing money from domestic stock mutual funds")

35 See Bhupathi, supra note 5, at 378 (explaining how high-frequency trading works and how it differs from traditional trading models).

36 Borrelli, supra note 12 , at 854.

37 See id.; see also 15 U.S.C. $\$ 78 \mathrm{f}$ (2006) (rules and regulations governing the creation of registered securities exchanges).

38 Borrelli, supra note 12, at 854.

39 See Hendrik Bessembinder et al., Why Designate Market-makers? Affirmative Obligations and Market Quality (Wayne State Univ. \& Univ. of Utah, Working Paper, 2007), available at http:/www.bnet.fordham.edu/yan/publications/Why\%20Designate\%20Market\%20Makers.pdf (discussing the role and value of market-makers in finance); see infra section $\mathrm{V}$ on the economics of market-making. 
providers was not voluntary. Specialists were required to provide market liquidity in accordance with the NYSE Byelaws and SEC Rules and Regulations. ${ }^{40}$

When the SEC was created, the rule regarding market-makers was fairly simple and straightforward; the SEC would not tell marketmakers how to make a market. ${ }^{41}$ The SEC simply required that exchanges choosing to use specialists disclose that usage to the SEC $;^{42}$ but because ninety-five percent of the volume went through the NYSE, the NYSE specialists were, as a result, the largest single group of market-makers in the industry. ${ }^{43}$ The NYSE specialists were, by default, responsible for providing trading liquidity to the equity market as a whole.

With the exchange-based specialists forced out by changes in monetary policy, high-frequency traders ostensibly filled the void and became the new (albeit unofficial) market-makers. ${ }^{45}$ High-frequency traders have become the new liquidity providers. The problem with this new paradigm is that the high-frequency traders-who have taken over the incredibly important role of providing liquidity to one of the most important marketplaces in the world ${ }^{46}$-have no obligation to provide market liquidity. ${ }^{47}$ NYSE specialists and other exchangebased market-makers ensured liquidity because they were subject to both SEC and exchange-imposed obligations. ${ }^{48}$ Because highfrequency traders participate in the equity market through alternative trading systems instead of exchanges, they are under no such obligation. ${ }^{49}$ Voluntary market-makers can withdraw their capital from the

40 See Simon \& Trkla, supra note 11, at 273.

41 Id. at 250 ("Section 11(b) required exchanges choosing to have specialist systems to register their specialists, as Congress initially proposed.").

42 Id.

43 MARKET 2000, supra note 21, at 8.

44 See generally Inside the NYSE: The Specialist, NYSE.COM, http://www.nyse. $\mathrm{com} / \mathrm{pdfs} / \mathrm{specialistmagarticle.pdf}$ (last visited Feb. 2, 2012) (informational release describing the duties of the NYSE specialists prior to their demise).

45 See Mehta, supra note 25.

46 See Jonathan R. Macey \& Maureen O'Hara, Regulating Exchanges and Alternative Trading Systems: A Law and Economics Perspective, 28 J. LEGAL STUD. 17, 17 (1999) ("C[apital] markets play an important role in America's economy. Indeed, the role played by capital markets in the United States is more important than the role played by such markets in European or Asian countries ...").

47 Id.

48 See Mao \& Pagano, supra note 3, at 51-52

49 See Adoption of Rule 11b-1 Under the Exchange Act of 1934, Exchange Act Release No. 34-7465, 29 Fed. Reg. 15862 (Nov. 26, 1964) (discussing how affirmative obligations were enforced through the self-regulatory components of the exchanges). 
market whenever they choose to do so, and history has shown that when the market takes a downturn, they often do.

This new category of market participant-the high-frequency trader-claims to provide market liquidity and yet is not bound by the same rules and regulations that the specialists once were. Because there are no SEC rules for how one must "make a market," there is, at present, no way to fill the void that was left by the departure of the affirmatively obligated specialists. This void must be filled. The role of the specialist evolved over more than a hundred years. ${ }^{51}$ It evolved to meet the needs of the market, but now, that role has been all but obliterated, and the market needs that the specialists once filled are not being met. Market liquidity is central to a healthy market. ${ }^{52}$ It dampens volatility, and it promotes consumer confidence. ${ }^{53}$ There are no longer enough active obligated market participants to ensure sufficient market liquidity. ${ }^{54}$ Since the early 1990s, as the number of alternative trading systems has risen, so has the level of volatility in the stock market. ${ }^{55}$ This is not a coincidence. The trading paradigm changed, and equity market regulation has not kept pace.

If the SEC wants to protect long-term investors (both individual and institutional) from the inherent dangers in this new paradigm, then the SEC needs to refine the definition of a market-maker and adopt a system of market-wide affirmative obligations. Taking this sort of action will make de facto markets (like high-frequency traders) into de jure market-makers. This process should begin with a re-

50 See ELECTRONIC BULlS AND BEARS, supra note 4, at 60-61.

For most of its history as a broker-dealer network, that is-before it registered as a national exchange in 2006 - NASDAQ employed market-makers who voluntarily provided contraside liquidity. During the 1987 stock market crash, one-third of the NASDAQ marketmakers withdrew from the market, thereby reducing liquidity even further and exacerbating the extreme volatility that was a part of the 1987 crash Id.

51 See Simon \& Trkla, supra note 11, at 222; see generally id. (chronicalling the history of the evolution of the specialist function).

52 See generally Jose Gabilondo, Leveraged Liquidity: Bear Raids and Junk Loans in the New Credit Market, 34 J. CORP. L. 447, 448 (detailing the relationship between different types of liquidity in the financial context and why liquidity is vital to credit markets).

53 See infra Section IV.

54 See U.S. COMmodity Futures Trading COMM'N \& U.S. SEC. AND EXCH. COMM'N, FINDINGS REGARDING THE MARKET EVENTS OF MAY 6, 2010: REPORT OF THE STAFFs OF THE CFTC AND SEC TO THE JOINT ADVISORY COMMITTEE ON EMERGING REGULATORY ISSUES 4-5 (2010) [hereinafter FLASH-CRASH REPORT], available at http://www.sec.gov/news/ studies/2010/marketevents-report.pdf.

55 See Macey \& O'Hara, supra note 46, at 46 (describing the constantly changing number of alternative trading systems and their proliferation); 20-Year Volatility Index for the S \& P 500 (VIX), http://finance.yahoo.com/echarts (search "VIX" in "get quote" field and set chart to "max" option). 
evaluation of the extremely outdated definition of a market-maker and the implementation of market-wide affirmative obligations for those market participants who act as market-makers. The new definition should include market participants with daily transactions above a certain intraday position threshold. Furthermore, the SEC needs to impose uniform affirmative obligations on these newly re-defined market-makers regardless of any other potential monikers they may hold. This will, in turn, level the playing field and create uniform standards for both official market-makers and de facto liquidity providers who hold themselves out as market-makers. Unimpeded highfrequency traders have taken the place of yesterday's obligated exchange-based specialists, becoming today's de facto market-makers. ${ }^{56}$ High-frequency traders wield tremendous power solely because of the volume that they control. Accordingly, these new players should be held accountable.

\section{CONTEXT: A HISTORICAL BACKGROUND}

\section{A. A Brief History of Equity Markets in the United States}

In the United States, organized markets for the purchase and sale of securities began to appear at the end of the eighteenth century. First in coffee houses, and later under the famed buttonwood tree, brokers and firms seeking to trade equity instruments began the process of laying out rules and regulations designed to bind their trading activities and ensure accurate price-discovery. ${ }^{58}$ These first selfregulating traders began the process of policing the early equity markets by adopting rules and regulations that would help ensure order and fairness. ${ }^{59}$ For example, one of these first rules was the concept of the fixed commission, which was implemented to promote civility and candor between trading members. ${ }^{60}$ These merchants and traders who conducted business within the walls of the Tontine coffee house would eventually become members of the New York Stock Exchange. ${ }^{61}$

For the better part of the next hundred years, the only meaningful securities regulation came from the exchanges where trading oc-

See Mehta, supra note 25.

MARKHAM, COLUMBUS, supra note 13, at 116-118.

58 See Stuart Banner, The Origin of the New York Stock Exchange, 1791-1860, 27 J. LEGAL STUD. 113,115 (1998).

59 MARKHAM, COLUMBUS, supra note 13, at 117-118.

60 See Markham \& Harty, supra note 15, at n.5 ("The agreement to fix commissions would be a mainstay of securities exchange trading until 1975 when the practice was banned by the SEC on 'May Day."').

61 MARKHAM, COLUMBUS, supra note 13 , at $123,189$. 
curred. $^{62}$ The rules, regulations, and policies that governed the actions of market participants (like the rule regarding fixed commission schedules) were formulated by each exchange. ${ }^{63}$ These policies changed as the markets grew. ${ }^{64}$ As the nature and size of the capital markets grew, the exchanges adapted their policies in order to continue to maintain consumer confidence.

There were a number of regional exchanges in the nineteenth century, but when it came to best practices, the NYSE was the largest and the most influential. ${ }^{66}$ The NYSE, like many other exchanges, operated an auction system. ${ }^{67}$ In the early years, the president would announce the stock and would then accept bids and offers. ${ }^{68}$ This auction system was the first organized marketplace for the sale of stocks and bonds in America, and it served an important price-discovery function. $^{69}$ For most of its history, the NYSE was organized as a notfor-profit trade organization. ${ }^{70}$ In order to participate in the auction, an individual ${ }^{71}$ would have to purchase a membership. ${ }^{72}$ Membership entitled the member to a "seat" at the auction. "In the exchange's first iteration, "seats" were actual chairs in the room where the auctions occurred." Eventually, the term "seat" became colloquial shorthand for an exchange membership. ${ }^{75}$ Only members could submit bids or offers, and members were not allowed to disclose the current prices to non-members. ${ }^{76}$ While these rules may, at first blush, appear elitist, they were not intended to be; rather they were intended to protect

\footnotetext{
See Markham \& Harty, supra note 15, at 874.

See Simon \& Trkla, supra note 11, at 22-3.

MARKHAM, COLUMBUS, supra note 13, at 328.

Id.

Banner, supra note 58, at 119.

Id.

68 MARKHAM, COLUMBUS, supra note 13, at 123 (describing the move from a call auction
} system to a continuous auction system).

69 J. EdWARd MeEker, The Work OF THE Stock Exchange 374-375 (The Ronald Press Co. 1930), available at http://books.google.com/books (search "the work of the stock exchange"); see also Markham \& Harty, supra note 15, at 882 (discussing the role of the exchange); see infra Section IV.

70 See White Paper, NYSE, Governance of the New York Stock Exchange, Inc. 5 (May 2003), available at http:// www.nyse.com/pdfs/governancewhitepaper.pdf.

71 New York Stock Exchange, NYSE EURONEXT, http://www.nyx.com/en/history/timeline (last visited Mar. 11, 2011) [hereinafter NYSE EURONEXT] (noting how member firms were not allowed to incorporate until 1953).

72 MARKHAM, COLUMBUS, supra note 13, at 123 (The initial cost of a membership was twenty-five dollars).

73 MEEKER, supra note 69, at 39.

74 Id.

75 Id.; see NYSE EURONEXT, supra note 71 (In 1868, memberships in the NYSE were deemed property rights which could be bought and sold).

76 MARKHAM, COLUMBUS, supra note 13, at 123. 
market participants during a time when there was virtually no other form of regulation. ${ }^{77}$ The NYSE started with only a handful of members, and eventually, in 1953, capped its membership number at $1366^{78}$ Memberships were initially owned by individuals and were nontransferable; but eventually, memberships came to be bought and sold by individuals and firms alike, in a manner similar to that used to transfer and hold title to other intangible property interests. ${ }^{79}$ The cap on memberships created a barrier to entry for most - the all-time high selling price for a seat was $\$ 4,000,000.00$ in $2005 .^{80}$ Nevertheless, it also allowed the NYSE to maintain control of its practices, thereby creating a certain level of order in the market for its listed stocks.

As the economy grew throughout the nineteenth century, stock exchanges went from relatively localized entities that dealt primarily in local issuances to national centers for commerce. ${ }^{82}$ Rapid industrialization and expansive railroad construction created a need for a safe venue for raising capital in order to fund these enterprises. ${ }^{83}$ As the U.S. infrastructure grew (both economically and geographically), so did the market for securities.

Although exchanges handled the majority of equity trading volume for most of the nineteenth and twentieth centuries, external trading has always existed. ${ }^{84}$ External trading is referred to as over-thecounter ("OTC") trading. In contrast to the exchange's auction system, historically, OTC trades were "negotiated" trades between individuals. ${ }^{86}$ One might call these transactions "private sales." Those individuals could be persons trading for their own purposes, or brokers that could not, or did not want to be a part of the exchange system. ${ }^{87}$ Alternative trading systems (and electronic matching networks) are simply a technological advancement of the OTC market.

\footnotetext{
77 See MEEKER, supra note 69, at 28-9.

78 Press Release, supra note 22.

79 Id.; see supra note 71 and accompanying text.

80 NYSE-Euronext, NYSE 2005 Year-End Review (Dec. 30, 2005), available at http://www.nyse.com/press/1135252289621.html.

81 See MARKHAM, COLUMBUS, supra note 13, at 328.

82 See generally MEEKER, supra note 68 (describing the growth of the New York Stock Exchange).

83 MARKHAM, COLUMBUS, supra note 13, at 156-157.

84 Michael J. Simon \& Robert L. D. Colby, The National Market System for Over-theCounter Stocks, 55 GEO. WASH. L. REV. 17, 19 (1986).

85 See id. (expressing that O.T.C. trading in equity securities dates back to the Revolutionary war).

$86 I d$. at 22 .

87 Id. at $22-23$.
} 
In a time when there was little to no government regulation, exchanges provided a sense of security. ${ }^{88}$ Exchange rules and regulations required vetting of companies and members. ${ }^{89}$ As the economy grew and the business of the exchanges boomed, the exchange listing standards became more stringent. ${ }^{90} \quad$ As self-regulatory organizations ("SROs"), the NYSE and other exchanges developed sophisticated systems of governance and protocol. ${ }^{91}$ Even the U.S. government recognized the value in retaining an organic system that grew directly out of the needs of the community. ${ }^{92}$ By the time Congress passed the Exchange Acts, the NYSE had been in existence (in one form or another) for more than a hundred years. ${ }^{93}$ Rather than start from scratch, Congress used the NYSE rules, regulations, and bye-laws as the foundation for the Exchange Acts. ${ }^{94}$

\section{B. An Overview of Relevant U.S. Equity Market Regulation and Legislation}

With very few exceptions, there were no securities laws prior to 1911. In 1911 (as a result of the 1907 panic) states began to adopt their own laws, but the era of meaningful securities regulation did not begin until 1933. ${ }^{95}$ The Securities Act of 1933 (the "1933 Act") was passed in 1933. ${ }^{96}$ The Exchange Act of 1934, (the "1934 Act"), which created the Securities and Exchange Commission, was passed the following year. ${ }^{97}$ The Securities Act of 1933 and The Exchange Act of 1934 (collectively referred to as the "Exchange Acts"), along with the self-regulatory functions of the exchanges, form the foundation of modern securities law and policy. The specific events and economic

88 See 2 Jerry W. MarkHam, A FinANCIAl History OF THE United States: From J.P. MORGAN TO THE INSTITUTIONAL INVESTOR (1900-1970) 4-5 (2001) [hereinafter MARKHAM, J.P. MORGAN].

89 See Markham \& Harty, supra note 15, at 882 (describing the role and value of exchanges).

90 MARKHAM, J.P. MORGAN, supra note 88, at 4-5.

91 Banner, supra note 58, at 115.

92 See Stavros Gadinis \& Howell E. Jackson, Markets as Regulators: A Survey, 80 S. CAL. L. REV. 1239, 1329 (2007) (describing the organic nature of the first federal securities regulation).

93 Banner, supra note 58, at 114.

94 Macey \& O'Hara, supra note 46, at 40 ("The Securities Act of 1933 and the Securities Exchange Act of 1934 simply codified existing NYSE rules, customs, and practices.”).

95 MARKHAM, J.P. MORGAN, supra note 88, at 59 ("Between 1910 and 1933, blue-sky laws were adopted in all of the states except Nevada. Nevertheless, those laws proved ineffective because they could not overcome the traditional legal rule of caveat emptor .... Moreover, the state could only regulate sales within their borders, which allowed interstate dealers to avoid most regulation."); see also Jonathan R. Macey, Origin of the Blue Sky Laws, 70 TEX. L. REV.347, 397 (1991) (detailing the rise of state securities laws).

96 Securities Act of 1933, Pub. L. No. 73-22, 48 Stat. 74 (1933).

97 Securities Exchange Act of 1934, Pub. L. No. 73-291, 48 Stat. 881 (1934). 
conditions that led to the first federal securities regulations are well beyond the scope of this article, but it is safe to say that the stock market crash of 1929 and the Great Depression precipitated the federal government's involvement in the regulation of the securities markets.

The Exchange Acts were based on the concept of transparency. Congress made it very clear that the intent of the legislation was to ensure that the potential investors had complete and truthful information, and that any decision on the merits of the investment was to be left in the hands of the investor. ${ }^{100}$ The mission of the newly formed Securities and Exchange Commission ("SEC") was "to protect investors, maintain fair, orderly, and efficient markets, and facilitate capital formation." The SEC would not make evaluations as to the merit of a particular investment, as long as the consumer had sufficient access to information to make an informed decision. ${ }^{102}$ This is in keeping with the principal ideologies of capitalism.

While the 1933 Act dealt primarily with issues surrounding stock issuances, the 1934 Act addressed the secondary market for equity instruments. $^{103}$ The 1934 Act was predicated upon the idea that the vast majority of securities transactions between retail customers and broker-dealers were and would continue to be executed through national exchanges. ${ }^{104}$ The 1934 Act established required stock exchanges to register with the SEC as national securities exchanges. ${ }^{105}$ By making the exchanges accountable to the SEC, the government was also in effect making the companies that listed on the exchanges accountable. The 1934 Act endorsed self-regulation, subject to federal oversight. ${ }^{106}$ Exchanges would continue to make their own rules and regulations, but new rules (and amendments to existing rules) had to be submitted for review and approved by the SEC before they could be enacted. ${ }^{107}$

98 See Elisabeth Keller \& Gregory A. Gehlmann, Introductory Comment: A Historical Introduction to the Securities Act of 1933 and the Securities Exchange Act of 1934, 49 OHIO ST. L.J. 329 (1988) (discussing the circumstances leading up to, and the legislative history of the Exchange Acts).

99 Id. at 330 .

$100 I d$.

101 What We Do, SEC. \& EXCH. COMM'N, http://sec.gov/about/whatwedo.shtml (last visited Feb. 2, 2012).

102 Manning Gilbert Warren III, Reflections on Dual Regulation of Securities: A Case Against Preemption, 25 B.C. L. REV. 485, 518 (1984).

103 Keller \& Gehlmann, supra note 98, at 339.

104 Borrelli, supra note 12, at 817 ("In passing the Exchange Act, Congress envisioned securities markets in which customers transacted business through broker-dealers and transactions were executed primarily on national exchanges.").

105 Securities Exchange Act of 1934, Pub. L. No. 73-291, 48 Stat. 881 (1934).

106 See Simon \& Trkla, supra note 11, at 238.

107 Id. 
By subjecting the exchanges' self-regulatory power to SEC oversight, Congress created a strong incentive for the NYSE and other exchanges to continue to enforce market protection measures. ${ }^{108}$

Although the 1934 Act was squarely aimed at regulating exchanges, trading that occurred outside of the exchanges (OTC trading) did not go unregulated for long. ${ }^{109}$ The 1938 Maloney Act was an amendment to the 1934 Act designed to target the OTC market. ${ }^{110}$ Like the 1934 Act, the Maloney Act was founded on the concept of self-regulation; however, the OTC market was unlike the exchanges in that the OTC market had no centralized organization ready to act in the capacity of self-regulator. ${ }^{111}$ In response to the Maloney Act, the National Association of Securities Dealers ("NASD") was created to act as a SRO for the OTC market. ${ }^{112}$ The broker-dealers who made up the NASD would eventually create NASDAQ, one of the first automated quoting systems.

In 1975, in response to a SEC study on the growth of institutional trading and technological innovation and inconsistencies in stock pricing between venues, ${ }^{114}$ Congress mandated the creation of a national market system. ${ }^{115}$ The idea behind the national market system was to create a new kind of securities market; one that would foster competition and provide fair access to quote information and trade execution through centralization. $^{116}$ It was thought that this would, in turn, lead to market efficiency and liquidity. ${ }^{117}$ One of the first changes that occurred as a result of the congressional mandate was the abolishment

108 See id.

109 MARKHAM, J.P. MORGAN, supra note 88, at 210.

110 United States v. Nat'l Ass'n of Sec. Dealers, Inc., 422 U.S. 694 (1975) ("The Maloney Act of 1938 [\$15A of the Securities Exchange Act of 1934] supplements the SEC's regulation.").

111 Get to Know Us, FINRA.ORG, http://www.finra.org/web/groups/corporate/@corp/ @about/documents/corporate/p118667.pdf. In 2007, the NASD and the regulatory committee of the NYSE merged into the Financial Industry Regulatory Authority ("FINRA"). FINRA is now the largest regulatory entity in the securities industry. Id. It is an independent organization that has taken over many of the tasks that were once the province of the self-regulatory arms of the exchanges. Id.

112 MARKHAM, J.P. MORGAN, supra note 88, at 210.

113 Market Mechanics, NASDAQ STOCK MKT. Educ. Found., INC. (2002), available at http://www.alcos.com/uploaded_pics/cmsimages/market_mechanics.pdf. NASDAQ would remain a quoting system until 2006 when it eventually registered with the SEC as a national exchange. Id.

114 Keller \& Gehlmann, supra note 98, at 307.

115 Equity Market Structure Concept Release, supra note 24, at 3596. The national market system concept was first implemented through the enactment of section 11A of the Exchange Act. Section 11A of the Exchange Act directed the Securities and Exchange Commission "to facilitate the establishment of a national market system." See id.

116 Id.

117 Macey \& O'Hara, supra note 46 at 17. 
of fixed commission schedules for brokerage trading. ${ }^{118}$ This change from a fixed commission schedule to a market bearing system was the first visible change in what would prove to be the largest shift in equity market structure in United States history. ${ }^{119}$

The model for the national market rested upon the congressional vision that the majority of securities business would continue to be transacted through broker-dealers who would, in turn, complete those transactions through national exchanges. ${ }^{120}$ The national market system concept would prove to be the driving force for SEC policy decisions for the rest of the twentieth century. ${ }^{121}$ Although the national market system concept was, in part, based on the idea that the growth of new technologies would help facilitate price-discovery and market efficiency, two things that the SEC could not see in 1975 were the extent to which the growth of technology would increase exponentially in the last two decades of the twentieth century and the effects that such growth would have on the landscape of equity markets. ${ }^{122}$

Regulation NMS ("Reg. NMS") (the current legislative iteration of the "national market system") is highly controversial ${ }^{123}$. In its attempt to create competition and to destroy the near monopoly that was the NYSE, Reg. NMS inadvertently destroyed the equity market's ability to police itself. $^{124}$ Because Exchanges are no longer in control of the lion's share of equity trading volume, they no longer have the power to enforce policies and procedures essential to the health of the equity markets, including the vital market-liquidity provision.

\section{From Exchange to Venues: The Shift}

Until the technological advent of computers, the definition of an exchange was simple. In much the same way that Justice Potter Stewart famously said of pornography: "I shall not today attempt further to define the kinds of material I understand to be embraced within that

118 SEC Statement on the Future Structure of the Securities Markets, 37 Fed. Reg. 5286, 5289 (Mar. 14, 1972).

1193 Jerry W. Markham, A Financial History of the United States: From the Age of Derivatives into the NeW Millenium (1970-2001) 29-30 (M.E. Sharpe 2001).

120 See Keller \& Gehlmann, supra note 98, at 339.

121 See generally Regulation NMS Adopting Release, Exchange Act Release No. 34-51808, 70 Fed. Reg. 37496 (June 29, 2005). Finally in 2005, after many years of heated debate and questions of how best to implement the objectives of the national market system, Regulation NMS replaced Section 11A. See id. The SEC issued the adopting release for Regulation NMS on June 29, 2005. See id.

122 See generally Bhupathi, supra note 5 (describing the concerns associated with highfrequency trading).

123 See Michael J. McGowan, The Rise of Computerized High Frequency Trading: Use and Controversy, 2010 DUKE L. \& TECH. REV. 16, 30-1 (2010).

124 See Mehta, supra note 25. 
shorthand description . . . but I know it when I see it." ${ }^{125}$ Everyone knew what an exchange was, and what it was not.

Beginning with Instinet in $1969,{ }^{127}$ followed by NASDAQ in $1970,{ }^{128}$ and then followed much later by the exchanges, ${ }^{129}$ equity market participants began using computers to transmit information. By 1990, the definition of what was and was not an exchange was very much up for debate. ${ }^{130}$ In the years between 1969 and 1990, the SEC reacted to these new electronic venues by issuing "no action" letters. In essence, each time the question of "whether a new venue was an exchange" would arise, the SEC would issue a letter releasing the electronic network from the obligations of registering as a national exchange (as defined by the 1934 Act). ${ }^{132}$ By 1990, it became clear that the problem would only continue to grow in size as technology became more advanced. $^{133}$ The SEC needed a more permanent solution.

The SEC had a problem: they had a Congressional mandate to facilitate the creation of a national market system. ${ }^{134}$ These new electronic networks were, under the legislation then in effect, most easily classified as "exchanges," but to classify these new entities as exchanges would likely stymie the growth of the national market system. It was, and still is, burdensome and extremely expensive to create a

125 Jacobellis v. Ohio, 378 U.S. 184, 197 (1964).

12615 U.S.C. $\$ 78$ c(a)(1) (1988) (providing that the statutory definition of exchange is "any organization, association, or group of persons, whether incorporated or unincorporated, which constitutes, maintains, or provides a market place or facilities for bringing together purchasers and sellers of securities or for otherwise performing with respect to securities the functions commonly performed by a stock exchange as that term is generally understood.").

127 Louise Corso \& Lewis D. Solomon, The Impact of Technology on the Trading of Securities: The Emerging Global Market and the Implications for Regulation, 24 J. MARSHALL L. REV. 299, 320 (Winter 1991).

128 MARKHAM, J.P. MORGAN, supra note 88, at 347 (describing the creations of the NASDAQ system).

129 See Final Rule: Regulation NMS, SEC. \& EXCH. COMM'N, 19, 23 (Aug. 2005), http://www.sec.gov/rules/final/34-51808.pdf (describing how exchanges initially created electronic systems in order to comply with the national market system mandate).

130 See generally Maynard, supra note 3 (discussing the history and problems associated with applying the term, "exchange" given the growth of electronic and proprietary trading).

131 Id. at 836 .

13215 U.S.C. $\$ 78 c(a)(1)$ (2012) (exchange definition).

133 See Maynard, supra note 3, at 881, 908; see also Delta Release, Exchange Act Release No. 34-27611, 55 Fed. Reg. 1890 (Jan. 19, 1990). In 1990, in response to Bd. of Trade of City of Chicago v. SEC, the SEC published the "Delta Release" clarifying the way that the SEC interpreted the term "exchange." Id. Moving forward the SEC would classify an exchange by focusing on the following features: centralizations, continuous two-sided trading, and the expectation of liquidity. $I d$. The Delta Release was a temporary measure which allowed the SEC to continue to issue no action letters while it formulated a more permanent solution to the "what are these new entities?" quandary. Id.; see also Bd. of Trade of City of Chicago v. SEC, 883 F.2d 525, 537 (7th Cir. 1989).

134 Securities Acts Amendments of 1975, Pub. L. No. 94-29, § 7, 89 Stat. 97, 111-117 (1975). 
nationally registered exchange. ${ }^{135}$ The amount of disclosure and preparation that goes into registering an entity as an exchange is substantial, in large part, because in order to register as a national exchange (which exchanges must do), one of the things that the organization had to prove to the SEC was that it had the means to carryout selfregulatory functions. ${ }^{136}$

The SEC's answer to its newfound problem was the eventual introduction of Regulation ATS ("Reg. ATS"); implemented in $1999 .{ }^{137}$ Reg. ATS was designed to be a flexible regulatory mechanism that allowed alternative trading systems (sometimes called electronic communications networks or proprietary trading systems) $)^{138}$ to register as broker-dealers instead of exchanges. ${ }^{139}$ Reg. ATS created a compromise-category for systems that did more than traditional OTC broker-dealers, but not as much as traditional exchanges; systems that did not provide a "continuous" market. ${ }^{140}$ According to Reg. ATS an "alternative trading system" is a marketplace that:

[B]rings together a buyer and a seller of a security in order to conduct activities commonly performed by a stock exchange, does not set out rules governing the conduct of those buyers and sellers (except as the conduct relates to trading activities), and does not discipline those buyers and sellers except by excluding them from trading. ${ }^{141}$

Reg. ATS effectually allowed automated systems and computer programs to carry out the functions traditionally performed by exchanges. $^{142}$ The enactment of Reg. ATS also meant that the paradigm of securities trade execution via human broker-dealers and exchanges was no longer the only way to trade. Suddenly, because of the collision of new technology and favorable government policy, there was an entirely new way to participate in the business of buying and selling securities.

135 See Simon \& Colby, supra note 84 , at 102.

136 Voluntary Submission of Rules for Commission Review and Approval, 17 C.F.R. $\S$ 40.5(a)(5).

137 Regulation of Exchanges and Alternative Trading Systems, Exchange Act Release No. 34-40760, 63 Fed. Reg. 70844 (Dec. 22, 1998) [hereinafter "Reg. A.T.S. Release”].

138 See Equity Market Structure Concept Release, supra note 24.

139 Reg. A.T.S. Release, supra note 137, at 70892-93.

140 Id. at 70854.

141 Id. (explaining how, in the Proposing Release, the Commission proposed to define the terms in the definition of "exchange" to be "any organization, association, or group of persons that: (1) consolidates orders of multiple parties; and (2) sets non-discretionary material conditions (whether by providing a trading facility or by setting rules) under which parties entering such orders agree to the terms of a trade.").

142 Id. at 70845. 
The push toward a national market system combined with Reg. ATS led to a proliferation of alternative trading systems. ${ }^{143}$ This, in turn, led to a drastic shift in the order flow of the equity markets. ${ }^{144}$ The purpose of the national market system and Reg. ATS was to create an environment that would allow for increased competition, and a fairer, more efficient market. ${ }^{145}$ To this end, Reg. NMS was fairly successful; the rise of electronic markets increased competition and reduced transaction costs. ${ }^{146}$ The access to pricing data and trade execution certainly became more equal than it once was, but the explosion of venues also had unintended consequences- consequences that run contrary to the good intentions of the national market system mandate. ${ }^{147}$ The move from traditional exchange-based trading to the more modern electronic trading platforms has left severe structural weak spots in the markets.

From the beginning of U.S. equity market trading, until the advent of electronic trading, market liquidity was almost never an issue. ${ }^{148}$ The existence of market liquidity was a given-an issue not requiring attention. ${ }^{149}$ The way that equity markets were structuredwith order flow being routed primarily through exchanges-ensured that sufficient liquidity would almost always be available because the exchanges made sure of it. ${ }^{150}$ Through the long process of trial and error, the entities responsible for guiding the structure of the markets created a system that protected the values of U.S. equity market fairness and safety. ${ }^{151}$ Then, almost overnight, everything changed. Between 1999 and 2011, the mechanics of how equity instruments were traded changed totally and permanently.

143 See Moyer \& Lambert, supra note 28.

144 See Mehta, supra note 25.

145 Macey \& O'Hara, supra note 46, at n.3.

146 Recommendations Regarding Regulatory Responses to the Market Events of May 6, 2010, Summary Report of the Joint CFTC-SEC Advisory Committee on Emerging Regulatory Issues, at *2 (Feb. 18, 2011), [hereinafter Feb 18, 2011 Panel Report], available at http:/www.cftc.gov/ucm/groups/public/@aboutcftc/documents/file/jacreport_021811.pdf.

147 Securities Acts Amendments of 1975, Pub. L. No. 94-29, § 7, 89 Stat. 97, 111-17 (1975).

148 See Borrelli, supra note 12, at 887 (discussing market fragmenting and the issues associated with the modern, contrary, paradigm).

149 Id.

150 See Bart Chilton, Commissioner, CFTC, Speech before the High Frequency Trading World, USA 2010 Conference, New York, NY: Speed (Dec. 8, 2010) (transcript available at http://www.cftc.gov/PressRoom/SpeechesTestimony/opachilton-35).

151 See generally Simon \& Trkla, supra note 11 (chronicalling the history of specialist and equity market regulation).

152 See Bhupathi, supra note 5. 
Market volume migrated en masse from exchanges to alternative trading systems, which in turn led to market fragmentation. ${ }^{153}$ The new decentralized paradigm has rendered traditional liquidity provision systems impotent and ineffective. The old design no longer works. In the current non-centralized market system, liquidity is no longer guaranteed. $^{154}$ In order to ensure liquidity in the current high-speed equity market structure, the SEC and other entities with the power to shape market structure need to take proactive, forward looking steps designed to protect investors and provide structure for the new future.

\section{ENSURING LIQUIDITY:THE VALUE OF MANDATORY MARKET- MAKING IN EQUITY MARKETS}

\section{A. Volatility and Liquidity in Financial Markets: In General}

A centralized market creates liquidity; this is known in economic terms as "the network effect." Alternatively phrased, "Liquidity attracts liquidity." "156 "As a single market attracts more and more trading volume in a stock, each new participant in that market enhances the value of the market to both existing and prospective participants by adding liquidity and thereby enabling that market to offer better prices." "157 This was one of the central ideas behind the original Congressional mandate that the SEC create a national market system. ${ }^{158}$ The other motivation was to create competition for the volume of stocks being traded. ${ }^{159}$ The thought was that competition would create better prices and lead to innovation. ${ }^{10}$

Trading-liquidity (also known as market-liquidity) is vital to virtually all financial markets. ${ }^{161}$ By way of an illustration, the Federal Reserve Board was created, in part, to ensure the liquidity of the U.S. banking system. ${ }^{162}$ After a series of panics and crashes, which culminated in 1907 when J.P. Morgan injected his own money into the U.S. banking system in order to prevent a meltdown, it became obvious to

153 See Gabriel Matus, The Regulation of Alternative Trading Systems: Market Fragmentation and the New Market Structure, 44 N.Y.L. SCH. L. REV. 583, 600-01 (2001) (describing market fragmentation as a result of the proliferation of alternative trading systems).

154 See Feb. 18, 2011 Panel Report, supra note 146.

155 Id. at 3.

156 Daniel M. Gray, The Essential Role of Regulation in Promoting Equity Market Competition, 1 BROOK. J. CORP. FIN. \& COM. L. 395, 407 (2007).

157 Id. at 397.

158 Securities Acts Amendments of 1975, Pub. L. No. 94-29, § 7, 89 Stat. 97, 111-17 (1975).

159 Id.

160 Id.

161 See generally Sanford J. Grossman \& Merton H. Miller, Liquidity and Market Structure, 43 J. FIN. 617 (1988) (explaining the value of liquidity to market quality).

162 MARKHAM, J.P. MORGAN, supra note 88, at 45. 
government leaders that they needed a more permanent way to keep the money supply liquid. $^{163} \quad$ In the equity markets, market-makers (and specifically exchange specialists) have traditionally supplied liquidity.

\section{B. Market-making and the Marketplace}

For almost two hundred years, the famed "Floor" of the New York Stock Exchange was the beating heart of financial capitalism. In a time when the most advanced technology available to businessmen was the telephone, the Floor served as a centralized marketplace for the buying and selling of securities. The Floor was more than just a place where stocks were bought and sold; ${ }^{166}$ it was a centralized marketplace that promoted the dissemination of information via the process of dynamic price-discovery. ${ }^{167}$ The price of a stock went up and down hundreds or thousands of times a day, depending on a variety of factors such as supply and demand, the timing needs of buyers and sellers, and the quantity of a given stock..$^{168}$

In other modern marketplaces, such as venues for the distribution and trade of fungible goods, the price-discovery process is far less dynamic than it is in securities markets. ${ }^{169}$ In other markets, the process of price-discovery generally occurs over a longer period of time. Sometimes that period is a day or two; for example, a gas station that changes its prices daily. Sometimes it is much longer. Some markets, like the real estate market, can take months or even years to respond to the influences of supply and demand. ${ }^{170}$ The timing of pricediscovery in each type of market represents different aspects of the health of the broader economy, but the price-discovery process that occurs in marketplaces such as the Floor of the NYSE is arguably the clearest indicator of how the introduction of new market information

163 Id. at 31.

164 See Grossman \& Miller, supra note 161, at 620-22.

165 See Borrelli supra note 12, and accompanying text.

166 See Mao \& Pagano, supra note 3, at 51-52.

167 Id.

168 Russell Olukayode et al., Determinants of Equity Prices in the Stock Markets, 30 INT'L RES. J. FIN. \& ECON. 177, 178 (Aug. 2009); Markham \& Harty, supra note 15, at 869. The NYSE was not an immediate success. It took many years for it to achieve its iconic status. Id.

169 See Torben G. Andersen et al., Real-Time Price Discovery in Stock, Bond and Foreign Exchange Markets, at 1-2 (Univ. of Penn. Working Paper, 2004), http://finance.wharton.upenn.edu/ rlwctr/papers/0421.pdf.

170 See generally Abdullah Yavas \& Yildiray Yildirim, Price Discovery in Real Estate Markets: A Dynamic Analysis, (Penn. State Univ. \& Syracuse Univ., Working Paper, 2006), http://www.reri.org/research/article_pdf/wp137.pdf (studying the price-discovery function in real estate markets and its relevance in the REIT market). 
is being absorbed and processed by market participants. ${ }^{171}$ Each fractional change in the price of a stock throughout the day is a response to what is going on in the world. Each trade executed at a given price is a reflection of information being introduced into the economy.

In the twenty-first century, the function of the marketplace is often taken for granted. This is likely because most market participants in first world countries never see the marketplace and its functions at work. Marketplaces that were once housed in physical locations (such as town squares and local bazaars) are now largely virtual. ${ }^{173}$ The Floor of the NYSE is no longer the largest financial marketplace in the world. ${ }^{174}$ The NYSE and many other physical marketplaces have, for the most part, been relegated to the realm of history books. ${ }^{175} \mathrm{Re}$ gardless of the fact that most marketplaces are no longer readily recognizable as such, it remains important to understand the function that the marketplace continues to serve. Even though the pricediscovery function that marketplaces facilitate now takes place (primarily) behind closed doors, it is important to remember that accurate price-discovery is still an essential component of healthy capital markets, and consistently accurate price-discovery requires a true marketplace, not just an automated order-routing system.

Regardless of how quickly it occurs, price-discovery is often facilitated by market-makers. In the broadest sense of the word, marketmakers are market participants who act as third parties between a buyer and a seller. ${ }^{177}$ Market-makers stand as intermediaries who are

171 See Jim Geraghty, The Market Isn't a Perfect Indicator of Economic Health, but Come on, Man, NAT. REV. ONLINE (Feb. 23, 2009, 11:13AM), www.nationalreview.com/campaignspot/7836/market-isnt-perfect-indicator-economic-health-come-man.

172 Id.

173 See H. Lee Murphy, Industry Trade Growing at Virtual Marketplaces, CRAIN's CHICAGO Bus. (Nov. 29 1999), http://www.chicagobusiness.com/article/19991127/ISSUE01/100013244/ industry-trade-growing-at-virtual-marketplaces.

174 Nina Mehta \& Nandini Sukumar, Intercontinental Exchange to Acquire NYSE for $\$ 8.2$ Billion, BLOOMBERG.COM (Dec. 20, 2012, 9:07PM), http:/www.bloomberg.com/news/2012-1220/intercontinentalexchange-said-in-merger-talks-with-nyse-euronext.html ("The Big Board, once the benchmark for global free markets, has seen its share of trading in stocks listed on the exchange decline to 21 percent from 82 percent.").

175 See Scott Patterson \& Geoffrey Rogow, What's Behind High-Frequency Trading, WALL ST. J., Aug. 1, 2009, at B1.

176 See George M. Giaglis et al., The Role of Intermediaries in Electronic Marketplaces: Assessing Alternative Hypotheses for the Future (Inst. for Info. Sys., Working Paper, 1999).

177 See John P. Gould, The Economics of Markets: A Simple Model of the Market-Making Process, 53 J. BuS. S167 (1980) (explaining the role of the market-maker in economic terms); Market-maker Entry, Electronic Commerce, ENCYCLOPEDIA OF INT'L MEDIA AND COMMC'NS, CREDo ReFERENCE (Oxford: Elsevier Science \& Technology, 2003) (Mar. 2010). 
wiling to help maintain market-liquidity. ${ }^{178}$ A very basic example of a market participant who acts as a market-maker is a corner grocer. He buys eggs and milk from the farmer in exchange for currency, and then the corner grocer turns around and sells the eggs and milk to the customer down the street in exchange for more currency. The price that he charges is influenced by supply and demand, timing, and the quantity of the desired product that is available. He generally makes some money on the difference between the price that he paid for the goods and the price that he sold the goods for. This is part of his incentive to be a party to the transaction. The corner grocer facilitates a transfer. If it were not for his willingness to buy and sell as an intermediary, costs would be much higher for both the farmer and the customer down the street. ${ }^{179}$ In short, the corner grocer's existence allows for accurate price-discovery between the original seller (the farmer), and the buyer (the customer down the street); but perhaps most importantly, the corner grocer provides market-liquidity.

During its heyday, the Floor of the NYSE was as much a marketplace as the corner grocery store is. It offered the most visible example of financial market-makers at work. ${ }^{180}$ When one looked at the action occurring on the Floor, most of the people milling about were floor brokers. Floor brokers were members of the exchange who executed both buy and sell orders for the purchase or sale of stocks. ${ }^{181}$ Most of those orders came into the Floor from outside representatives (usually registered broker-dealers), who had taken orders from enduser customers. ${ }^{182}$ The other people on the Floor, the people who were tied to their stations (historically known as "booths") were the spe-

178 See generally Maureen O'Hara \& George S. Oldfield, The Microeconomics of Marketmaking, 21 J. FIN. \& QUANTITATIVE ANALYSIS 361 (1986) (explaining the market-maker's role as financial intermediary).

179 See Gould, supra note 177, at S167 (explaining the role of the market-maker in economic terms).

180 See Market Mechanics, supra note 113 (explaining that different stock exchanges and trading venues use different titles for the categories of market participants, but the roles are essentially the same).

181 See ELECTRONIC BULlS AND BEARS, supra note 4, at 43-44 (illustrating and explaining the mechanics of how a stock order was routed and executed prior to the NYSE's demutualization and the dissolution of the specialist).

182 FINRA Registration and Examination Requirements, FINRA.ORG, http://www.finra.org/Industry/Compliance/Registration/QualificationsExams/Qualifications/p011 051 (last visited Feb. 2, 2012) (noting that a General Securities Representative is an individual who is qualified to participate in the business of "the solicitation, purchase, and/or sale of all securities products, including corporate securities, municipal securities, municipal fund securities, options, direct participation programs, investment company products, and variable contracts.”). 
cialists. ${ }^{183}$ A specialist was also a member of the exchange, but a specialist had gone through additional vetting procedures and was subject to certain affirmative and negative obligations. ${ }^{184}$ As market-makers, the specialist stood ready to buy or sell when there was market illiquidity. ${ }^{185}$ If a seller wanted to sell his stock, and there was no end buyer readily available, the specialist would purchase the stock and keep it in his own account. ${ }^{186}$ Once the order got to the specialist, the next step would depend on market conditions, but generally, the order would either be matched with a sell order from another floor broker, or the specialist would fill the order himself (if need be). ${ }^{187}$ In addition to providing contra-side liquidity, the specialist was charged with maintaining a "fair and orderly market[place]" and acting as agent for floor brokers who left unfulfilled orders with the specialist.

Specialists and other financial market-makers traditionally wielded great power; with that power came strict regulation-from both the exchange and the SEC. As previously illustrated, the role of the market-maker is vitally important to the way that capital markets function. Yet, as the mechanics of equity trading have changed, the specialists and other financial market-makers have been all but driven out of the markets that they once guided and controlled. ${ }^{189}$ In their place, a totally new category of market participant has risen.

\section{MARKET-MAKING \& LIQUIDITY PROVIDERS IN U.S. EQUITY MARKETS:THEN AND NOW...}

\section{A. Specialists as Market-Makers: The Historical Liquidity Providers}

In the context of equity markets, a market-maker is a brokerdealer firm that "maintains a firm bid and offer price in a given security by standing ready to buy or sell at publicly-quoted prices." fact that there is a broker-dealer standing ready to buy a stock (or sell

183 See Joel Hasbrouck et al., New York Stock Exchange Systems and Trading Procedures, 3 (N.Y.U. Stern School of Bus., Working Paper No. 93-01, 1993), available at http://pages.stern.nyu.edu/ jhasbrou/Research/Working\%20Papers/NYSE.PDF.

184 See Simon \& Trkla, supra note 11, at 224.

185 See Macey \& O’Hara, supra note 46, at 2.

186 See id.

187 See Simon \& Trkla, supra note 11, at 226; Market Mechanics, supra note 113; Hasbrouck, supra note183.

188 See Inside the NYSE: The Specialist, supra note 44.

189 Press Release, NYSE Euronext, NYSE Proposes Changes to Specialist Capital Requirements, (May 26, 2005) (available at http://www.nyse.com/press/1115807746493.html) ("In 2000, 25 specialist organizations were operating on the Floor of the Exchange. Today, there are seven.").

190 Glossary of Terms, FINRA, http:/www.finra.org/Glossary/p011116 ("market-maker" entry) (last visited Jan. 28, 2013). 
a stock) when there is very little contra-side liquidity for that stock promotes investor confidence and prevents panic. ${ }^{191}$ It also decreases pricing volatility by temporarily closing the gap between what a buyer is willing to pay and what a seller is willing to accept. ${ }^{192}$ In short, it creates market stability, which, in turn, instills investor confidence in the stock market. It also (often times quite silently) creates confidence in the economy as a whole.

As previously stated, the NYSE market-makers were known as specialists. $^{193}$ In 1871, due to the increased trading volume, the NYSE went from an auction system in which the exchange auctioned off one stock at a time at periodic intervals during the day to a continuous two-sided auction system. ${ }^{194}$ In the continuous auction system each stock was assigned to a station and a specialist was assigned to each stock. $^{195}$ From 1871 onward, bids and offers were placed with the specialist for that stock, and the specialist acted as a broker's broker, an

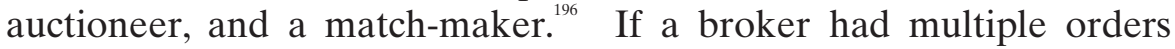
from multiple clients at the same time, he could not treat all of the orders fairly because he could only be on one auction station at a time. The specialist system solved the broker's problem of only being able to be in one place at one time. ${ }^{197}$ The specialist was created as an answer to this problem.

Each specialist was by definition, a broker. ${ }^{199}$ Specialists had a book (known as a "limit order book" or simply "the book") where they would record each bid and offer and act as the auctioneers, using a first-in, first-out approach to match bids with offers. ${ }^{200}$ Because these specialists had access to the book, they also had the ability to see both the relevant bid and offer at the same time. ${ }^{201}$ This so-called "time and place" advantage was seen as unfair, so in exchange for this benefit, specialists were assigned duties and obligations as a sort of quid pro

191 Simon \& Trkla, supra note 11, at 52.

192 Id.

193 See Kurt W. Rotthoff, How Market Makers Affect Efficiency; Evidence Markets are Becoming Less Efficient 18 CAP. MKTS. REV. 53, 57 (2011).

194 NYSE EURONEXT, supra note 71 ("To foster more liquid markets, the Exchange adopts a system of continuous trading, replacing calls of stocks at set times. As part of the new system, brokers dealing in a particular stock remain at one location on the trading floor, giving rise to the Specialists.").

195 Simon \& Trkla, supra note 11, at 223-24.

196 ELECTRONIC BULLS \& BEARS, supra note 4, at 52 (pointing out that the specialist quirk of one specialist for each stock occurred over time-eventually reaching its end result in 1967).

197 Simon \& Trkla, supra note 11, at 223.

198 See id.

199 Id.

200 Id. at 227.

201 Id. 
$q u o .^{202}$ The fact that specialists were also brokers created an obvious conflict of interest. ${ }^{203}$ The broker's brokers were their own brokers. In an attempt to curb potential abuses resulting from this conflict of interest, in 1935 the SEC imposed a rule on exchanges that employed the use of specialists. ${ }^{204}$ This rule imposed "negative obligations" on the specialists. ${ }^{205}$ These negative obligations meant that the specialists were not allowed to trade for their own accounts in their specialty stock unless such a trade was "reasonably necessary" to maintain a fair and orderly marketplace. ${ }^{206}$

In addition to the negative obligations placed on the specialists, as their role evolved, the NYSE and the SEC began to impose "affirmative obligations" on the specialists, eventually making the obligations mandatory in $1964 .^{207}$ In exchange for the so called "time and place" benefits that the specialists enjoyed by being on the floor and having access to the book, the newly imposed affirmative obligations required specialists to commit their own capital to take the other side of a trade if there was no open market counter-party to the trade. ${ }^{208}$ This affirmative obligation rule helped ensure a fair and orderly market. $^{209}$ By requiring specialists to act as buyers or sellers in times of market illiquidity, the SEC (through the NYSE) used specialists to ensure market liquidity; this liquidity created market stability during times of panic. ${ }^{210}$ If an arm's length buyer (or seller) was not available for a given stock, the specialist would place himself in that role, thereby decreasing the level of volatility in the price of stocks and in the market as a whole. ${ }^{211}$ Alternatively put, specialists created a buffer zone in times of market panic. By ensuring market liquidity, the panic that would inevitably ensue as the result of a market participant's inability to freely and easily move his stock was avoided. ${ }^{212}$

202 Id.

203 Id.

204 Negative Obligations, Exchange Act Release No. 179, 1935 SEC LEXIS 145 (Apr. 17, 1935).

205 Id.

206 Saperstein Interpretation, Exchange Act Release No. 1117, 1937 SEC LEXIS 357 (Mar. 30,1937 ) (issuing more detailed guidelines for what was and was not allowed under the negative obligation rules).

207 Affirmative Obligations, Exchange Act Release No. 34-7465, 29 Fed. Reg. 15862 (Nov. 26, 1964).

208 Simon \& Trkla, supra note 11, at 217.

209 See Simon \& Trkla, supra note 11, at 221.

210 See MARKET 2000, supra note 21, at 4.

211 Simon \& Trkla, supra note 11, at 222.

212 See Mao \& Pagano, supra note 3, at 52. 
In 1964, in response to a nearly nine hundred-page study on potential market manipulation, Congress amended the Exchange Act. ${ }^{21}$ This study (hereinafter referred to as "the Special Study") was commissioned, in part, because of concerns of abuses taking place in the equity markets, including but not limited to abuses perpetrated by exchange specialists. ${ }^{214}$ The Special Study remains, to date, one of the most comprehensive studies ever done on equity market structure. ${ }^{215}$ The Special Study found that there were serious problems with the regulatory structure of the securities markets. ${ }^{216}$ The SEC found that many of the problems were due to their own lack of intervention and the industry's inability to keep pace with the tremendous amount of growth that occurred in the preceding twenty-five years. ${ }^{217}$ The SEC was quick to note, however, that it was not the underlying regulatory structure that was lacking; rather, the structure simply needed enforcement and expansion, which would take into account the changed landscape. $^{218}$ In essence, the SEC was admitting that it needed to do more. This particular report and the regulatory changes that resulted are similar to the situation that exists today. The SEC has the power to make changes, but thus far it is not using the power that it has taken responsibility for. ${ }^{219}$

Specialists were not exclusive to the NYSE. They existed in most exchanges although the specific form that their affirmative or negative obligations took was dependent on the rules and regulations of the exchange to which they belonged. ${ }^{220}$ It is worth noting here that al-

213 See generally Special Study, supra note 11.

214 Id.

215 Id.

216 Simon \& Trkla, supra note 11 , at 286.

217 Id.

218 Id. at n.447 (The Commission stated that the large number of companies going public, the "spectacular development of the over-the-counter market" and the increased participation of public investors "imposed strains on the regulatory system and revealed structural weaknesses.").

219 Press Release, FINRA, NASD and NYSE Member Regulation Combine to Form the Financial Industry Regulatory Authority - FINRA, available at http://www.finra.org/Newsroom/NewsReleases/2007/p036329 ("The Financial Industry Regulatory Authority (FINRA) today announced that it has commenced operations as the largest nongovernmental regulatory organization for securities brokers and dealers doing business in the United States. FINRA was created through the consolidation of NASD and the member regulation, enforcement and arbitration operations of the New York Stock Exchange. The consolidation, which was announced on Nov. 28, 2006 and approved by the Securities and Exchange Commission on July 26, 2007, became effective today, July 30, 2007.”).

220 Equity Market Structure Concept Release, supra note 24, at n.70 ("Affirmative and negative obligations generally are intended to promote market quality. Affirmative obligations might include a requirement to consistently display high quality, two-sided quotations that help dampen price moves, while negative obligations might include a restriction on 'reaching across the market' to execute against displayed quotations and thereby cause price moves."). 
though most exchanges had market-maker positions (like specialists), the fact that the NYSE was by far the largest exchange in the world for more than a hundred years makes it the most relevant example of market-making at work. The Special Study was also the starting point for non-exchange based equity market-makers. ${ }^{221}$ The suggestions put forth in the Special Study lay the foundation for NASD marketmakers. ${ }^{222}$ The SEC was attempting to move the independent brokerdealers of the NASD to a more exchange-like setup, but (foreshadowing what was to come) unlike NYSE specialists, NASD market-makers were not "obligated" to provide contra-side liquidity-and this was a problem. $^{223}$ NASD market-makers were also unlike NYSE specialists in that there was more than one market-maker for each stock in the OTC market. ${ }^{224}$ The NYSE had only one specialist per stock. ${ }^{225} \mathrm{Be}-$ cause there was competition between the NASD market-makers for each stock, and because prior to the advent of high frequency trading there was money to be made in voluntary market-making, NASD market-makers often provided contra-side liquidity because it was a good way to make money.

\section{B. Why the Specialists Left the Floor}

Specialists made money through a commission system. ${ }^{227}$ This system was profitable because the U.S. stock markets traded in eighths until $1997 .^{228}$ Specialists made money by putting the difference between what they bought the stock for and what they sold it for in their pockets. $^{229}$ On each trade, they stood to make at least an eighth of a dollar or, twelve and a half cents. ${ }^{230}$ When the stock market transitioned from trading in eighths to trading in sixteenths, and then finally, to trading in pennies (often called "teenies"), there was no longer

221 See id. at 292.

222 See Corso \& Solomon, supra note 127 , at 312.

223 See id.; see also ELECTRONIC BULLS \& BEARS, supra note 4, at 60-61 (illustrating some of the problems associated with voluntary market-making).

224 Simon \& Colby, supra note 84 , at 88.

225 Id.

226 See Special Study, supra note 11, at 661; see also supra text accompanying note 50.

227 See MEEKER, supra note 69, at 77.

228 See generally Michael A. Goldstein \& Kenneth A. Kavajecz, Eighths, Sixteenths, and Market Depth: Changes in Tick Size and Liquidity Provision on the NYSE, 56 J. FIN. ECON. 125, 126 (2000). From 1817 until 1997, bids and offers were made in increments of an eighth of a dollar. Id. Trades continued in eighth increments until 1997, when the spread was narrowed to sixteenth increments. In 2000, the decision was made to further reduce the spread to penny increments. This move to penny increments is known as decimal pricing, or decimalization. Id.

229 Simon \& Trkla, supra note 11, at 261.

230 Goldstein \& Kavajecz, supra note 228, at 127. 
enough of a margin for specialists to make money on their trades. ${ }^{231}$ This push to change the trading denomination came from the SEC. ${ }^{232}$ The specialists' potential profit margin was essentially cut from twelve and a half cents to one cent (or less), thereby reducing their potential income by upwards of ninety percent. In 2010, in light of the changing role of specialists and their ever-decreasing numbers, the NYSE changed the duties and renamed the specialists "Designated Marketmakers." had kept the wheels of the economy turning for more than a hundred years.

This change in monetary policy essentially put the specialists out of business. $^{234}$ When they left the floor of the exchange, they took the liquidity function that they provided with them. ${ }^{235}$ Around this same time (and also as a product of the national market system mandate), there was a swell in the number of alternative trading systems. ${ }^{236}$ The market share that had once belonged to the NYSE was very quickly being divvied up between dozens of new alternative venues. ${ }^{237}$ The landscape of the equity markets changed almost overnight. ${ }^{238}$

\section{High Frequency Traders: 21st Century De Facto Market-Makers}

The SEC does not publicly support an official definition of high frequency trading. ${ }^{239}$ In practice, high frequency trading is exactly what it sounds like. ${ }^{240}$ Computer algorithms place large volume trades at a speed much too fast for human comprehension. ${ }^{241}$ The profitability of high frequency trading grew out of the regulatory and policy changes that Reg. ATS and Reg. NMS put in place. Reg. ATS allowed alternative trading systems to register as broker-dealers instead of exchanges, thereby making it possible for more competitors to enter the market. ${ }^{24}$ Reg. NMS (in its final iteration) required that market orders-orders designated to be executed at the current "market price"-be posted

231 Id.

232 See id. at 125-26.

233 Chapman, supra note 8.

234 See Mehta, supra note 25.

235 Id.

236 Id.

237 Id.

238 See Michael J. McGowan, The Rise of Computerized High Frequency Trading: Use and Controversy, 2010 DukE L. \& TECH. REV. 16, II 1 (2010).

239 Equity Market Structure Concept Release, supra note 24, at 3606.

240 See Patterson \& Rogow, supra note 175.

241 Id.

242 Reg. A.T.S. Release, supra note 137, at 70905. 
electronically and be executed at the best available price nationwide. ${ }^{243}$ This part of Reg. NMS was designed to create price transparency via

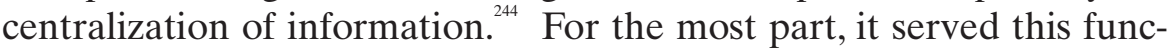
tion, but it also created a new and lucrative market for high frequency traders. ${ }^{245}$ Specialists were forced out of the market because they could no longer make money on the spread, ${ }^{246}$ but by executing an exceedingly large number of trades, high frequency traders could make a profit on even the smallest of margins. ${ }^{247}$ Also part of Reg. NMS was a shift in regulatory power. ${ }^{248}$ The SRO function that had rested with the NYSE and its equivalent exchanges was consolidated into a new quasi-governmental agency known as FINRA. ${ }^{249}$ This consolidation of power meant that the NYSE no longer had any real ability to selfpolice. $^{250}$

High frequency traders do not just make money because of the tremendous volume of trades that they execute. In addition to the profit margins that they collect for each trade, high frequency traders (like specialists before them) make money by accepting rebates from exchanges. $^{251}$ These rebates are paid out to the high frequency traders in exchange for directing order flow toward the exchanges. ${ }^{252}$ High frequency traders also make money via the so-called "latency arbitrage." $" 253$ These trades happen so fast that there is a latent period during the time it takes the data to cross the electronic network. ${ }^{254}$ This time lag creates an opportunity for those with the fastest computers and those closest to the trading centers to profit off of any pricing

243 McGowan, supra note 238, at II 13.

244 See id. at n. 39.

245 Id.

246 See generally Goldstein \& Kavajecz, supra note 228 (explaining the concept of "the spread," and illustrating how the mechanics of trading functioned prior to decimalization).

247 Moyer \& Lambert, supra note 28.

248 Press Release, FINRA, NASD and NYSE Member Regulation Combine to Form the Financial Industry Regulatory Authority - FINRA, available at http://www.finra.org/Newsroom/NewsReleases/2007/p036329 ("The Financial Industry Regulatory Authority (FINRA) today announced that it has commenced operations as the largest nongovernmental regulatory organization for securities brokers and dealers doing business in the United States. FINRA was created through the consolidation of NASD and the member regulation, enforcement and arbitration operations of the New York Stock Exchange. The consolidation, which was announced on Nov. 28, 2006 and approved by the Securities and Exchange Commission on July 26, 2007, became effective today, July 30, 2007.”).

249 Id.

250 Id.

251 Patterson \& Rogow, supra note 175. Most exchanges are willing to pay a rebate fee, usually a third of a penny a share, to venues willing to circulate volume through the exchange. Id. This creates liquidity in the exchanges, but it is an entirely carrot based system. Id.

252 See id.

253 Equity Market Structure Concept Release, supra note 24, at 3608.

254 See Patterson \& Rogow, supra note 175. 
changes that occur in the milliseconds that it takes to transmit trading data.

In order to execute the kind of trades that high frequency traders participate in, they have to place a massive number of bids and offers. ${ }^{256}$ Advocates of high frequency trading claim that high frequency trading injects liquidity into the markets. ${ }^{257}$ High frequency traders do provide liquidity to the markets, but they do not ensure liquidity in the markets. This distinction is often ignored when proponents of high frequency trading discuss the benefit that it provides for the markets. High frequency traders have no obligation to remain in the markets in times of crisis.

The role of high frequency trading in the future of equity markets is a hot button topic. Proponents claim that high frequency trading is the way of the future. ${ }^{258}$ With everyone struggling to get a piece of the high speed pie (exchanges included), they may well be right. ${ }^{259}$ Those that are fundamentally opposed to high frequency trading as a way of doing business lament the destruction of equity markets at the hands of technology run amuck. ${ }^{260}$ Regardless of the position that one takes, it is undeniable that the rise of high frequency trading has raised a number of concerns. Nowhere is this more clearly illustrated than by the SEC itself, in its January 2010 "Concept Release on Equity Market Structure." ${ }^{261}$ In this particular concept release, one of the main issues that the SEC asked for comment on was high frequency trading. ${ }^{262}$

By most estimates, high frequency trading now accounts for at least fifty percent of equity market volume (some estimates place the number as high as seventy percent). ${ }^{263}$ Given the primary role that this relatively new creature plays in post Reg. NMS equity markets, the SEC needs to evaluate and address how and to what extent high frequency trading needs to be regulated. First, how is high frequency trading to be defined? There is no set definition for high frequency trading. ${ }^{264}$ The term "high frequency trading" encompasses everything

255 Moyer \& Lambert, supra note 28; see also McGowan, supra note 238, II 16, II 20 (offering examples of how, because of the vast benefits of co-location, there has been a recent rush for real estate proximate to the exchanges. sometimes costing an astronomical amount, but firms are willing to pay for it) (e.g. in Chicago, 6 square feet of space in the data center where the exchanges also house their computers can go for $\$ 2,000$ or more a month.) $I d$.

256 Moyer \& Lambert, supra note 28.

257 Id.

258 Spicer \& Lash, supra note 27.

259 Id.

260 Moyer \& Lambert, supra note 28.

261 Equity Market Structure Concept Release, supra note 24, at 3606.

$262 I d$.

263 Id. at n.67.

264 Id. at 3607. 
from algorithms put in place by companies like e-trade, to so-called "dark pools" of liquidity, internal proprietary trading done in-house within brokerage houses. ${ }^{265}$ Other concerns focus on the strategies used by high frequency traders. ${ }^{266}$ Is there a need for more regulation, or are the regulations already in place sufficient? Is this a situation in which specific regulation is called for, or are the tools and strategies used by high frequency traders the bucket shops of the electronic age?

The argument over high frequency trading and how it should be treated going forward is a very complex issue. There are arguments that high frequency trading should be banned altogether. ${ }^{267}$ Some say high frequency trading runs contrary to the purpose of equity markets (capital formation). ${ }^{268}$ Others say that the tools used by high frequency traders manipulate the underlying fundamentals of equity markets. ${ }^{269}$ The counter argument claims that high frequency trading enhances the marketplace for everyone by reducing the execution time on trades, narrowing price spreads (furthering the market wide goal of price-discovery), and providing liquidity.

For better or for worse, high frequency trading currently accounts for the majority of the transaction volume in today's equity markets. ${ }^{271}$ Because of their role as the "new" liquidity providers and the fact that they are, in effect, passive market-makers, high frequency traders and the regulation of their activities has been analogized to that of specialists. $^{272}$ Some have suggested that because the role that the specialists once played is similar to the role that high frequency traders currently play, the high frequency traders should be subject to affirmative obligations like their predecessors were. ${ }^{273}$

There are two primary arguments set forth by those that advocate for mandatory affirmative obligations being imposed upon high frequency traders. The first argument is based on the theory that because high frequency traders have extremely powerful, highly sophisticated systems for order routing, execution, and cancellation, they have an advantage over other market participants. ${ }^{274}$ Proponents of this argu-

\footnotetext{
$265 I d$.

266 Id.

267 Moyer \& Lambert, supra note 28.

268 Letter from Jeffrey A. Blaker to the Sec. \& Exch. Comm'n, Responding to the Commission's Concept Release on Equity Market Structure (Apr. 17, 2010), available at http://www.sec.gov/comments/s7-02-10/s70210-110.pdf.

269 See Moyer \& Lambert, supra note 28; Simon \& Trkla, supra note 11, at 311 (Similar concerns were also voiced during the 1972 special study sessions.).

270 Spicer \& Lash, supra note 27.

271 Equity Market Structure Concept Release, supra note 24, at 3606.

272 Id. at 3607.

273 Id.

274 Moyer \& Lambert, supra note 28.
} 
ment claim that because trade execution in today's market is highly automated, the highly complex, expensive systems that high frequency traders employ are akin to the time and place advantage that specialists once enjoyed. $^{275}$

The second argument set forth for the imposition of affirmative obligations on high frequency traders is also based on an analogy to the specialists' time and place advantage. ${ }^{276}$ This argument is based on the theory that co-location gives high frequency traders a benefit not enjoyed by others in the market. ${ }^{277}$ Co-location is the term used to describe the benefit that trading centers enjoy by physically locating their servers close to trading centers. ${ }^{278}$ Co-location centers are used by the owner of the system and are also rented out to other systems. ${ }^{27}$ In a market where milliseconds count, the value of real estate close to exchange centers is essential. ${ }^{280}$ For example, in Chicago, six square feet of rack space in the building where the Chicago exchanges house their servers can rent for $\$ 2,000.00$ a month. ${ }^{281}$

Both of these major arguments for the imposition of affirmative and negative obligations upon high frequency traders (due to the analogous relationship that high frequency traders share with specialists of the past), fail miserably. The rationale is fallacious. Advocates are looking for someone to blame for the current situation, and, while analogy is a wonderful tool (without which the law as we know it would not exist), in this particular case, to use analogous reasoning to draw connections between regulations of a past paradigm and a new one is quite simply an abysmally weak argument. This new paradigm is a long way from the origins of U.S. equity markets, and it needs to be evaluated as such.

\section{AN ARGUMENT FOR MANDATORY OBLIGATIONS FOR TODAY'S "NEW MARKET-MAKERS"}

\section{A. New Market, New Rules}

As the structure of the equity markets has changed, so has the role of regulators. The Exchange Acts and the implementation of the national market system were both predicated upon the belief that the

275 Id.

276 See Equity Market Structure Concept Release, supra note 24, at 3607-08.

277 Graham Bowley, The New Speed of Money, Reshaping Markets, N.Y. TIMES (Jan. 1, 2011), http://www.nytimes.com/2011/01/02/business/02speed.html?pagewanted=all.

278 See Spicer \& Lash, supra note 27.

279 Moyer \& Lambert, supra note 28.

280 Id.

281 Id. 
majority of volume would continue to be circulated through exchanges. ${ }^{282}$ The exchanges were then, as now, subject to significant regulatory oversight. ${ }^{283}$ The rise of alternative trading systems (and high frequency trading in particular) has created a situation where the majority of the equity market volume is no longer being directly routed through exchanges. ${ }^{284}$ Equity market-making in the digital age has a gaping hole in its foundation-a hole large enough for a threering circus.

The SEC should impose affirmative obligations on marketmaking high frequency traders but not because they share some tenuous connection with the market-makers of the past. The SEC should impose regulatory obligations on high frequency traders because, even by conservative estimates, high frequency trading accounts for more than fifty percent of the volume of trades executed in equity markets. ${ }^{285}$ These new liquidity providers can literally move markets, and with them, the global economy. ${ }^{286}$ Any market participant group that wields that much power over the heart of the world economy cannot be left unsupervised to guard the proverbial hen house.

American equity markets lie at the heart of the economy. During the initial exploration of the idea of a national market system, Congress stated that securities markets are an "important national asset that must be preserved and strengthened." ${ }^{287}$ Congress went on to say:

National emergencies, which produce widespread unemployment and the dislocation of trade, transportation, and industry, and which burden interstate commerce and adversely affect the general welfare, are precipitated, intensified, and prolonged by manipulation and sudden and unreasonable fluctuations of security prices and by excessive speculation on such exchanges and markets, and to meet such emergencies the Federal Government is put to such great expense as to burden the national credit. ${ }^{288}$

Market-makers play an important role in providing liquidity to financial markets. $^{289}$ There are a number of peer-reviewed studies support-

283 Moyer \& Lambert, supra note 28.

284 See Mehta, supra note 25.

285 Equity Market Structure Concept Release, supra note 24, at n.70.

286 See Chilton, supra note 150.

287 Securities and Exchanges, Necessity for Regulation, 15 U.S.C.S. § 78b (1934).

288 Id.

289 See generally Amber Anand \& Daniel G. Weaver, The Value of the Specialist: Empirical Evidence from the CBOE, 9 J. FIN. MKTS. 100, 102 (2006) (explaining the value of the specialist in equity markets). 
ing the use of market-maker obligations in order to bolster market quality. ${ }^{290}$ The primary means of accomplishing this task is either by providing incentives or by imposing regulations (affirmative obligations) which lead to meaningful liquidity in times of crisis. ${ }^{291}$ Although there are focused marketplaces wherein incentive based marketmaking is sufficient to provide necessary liquidity, the global equity market is not insulated enough to work solely on an incentive based system. $^{292}$ The 1964 Special Study provides ample support for this theory. $^{293}$ The exchanges were initially forced to impose affirmative obligations on their specialists because the specialists could not be trusted to refrain from taking advantage of their power without some kind of accountability.

High frequency traders do provide liquidity to the equity markets, but they do not ensure liquidity. They are under no obligation to stay in the market. In order for market-makers to have value to the market, they must be bound at least some of the time; they must be truly obligated. ${ }^{295}$ High frequency traders have no such obligation. The liquidity function that they claim to provide replaced a liquidity function that was provided by market participants who were subject to true obligations. ${ }^{296}$ High frequency traders provide liquidity. The problem with this statement as an argument against regulation is that although high frequency traders do provide liquidity, they also consume liquidity. ${ }^{297}$ How they choose to interact with the market is based on algorithmic risk profiles that are continually re-assessed. ${ }^{298}$ So, while high frequency traders do inject liquidity into the markets at certain points throughout the trading day, whether they are liquidity providers or consumers depends on what time of day it is and the choices that their computer programs make. ${ }^{299}$

Traditionally, because of their control of the majority of trading volume, ensuring liquidity and avoiding unnecessary volatility was the

290 Id.

291 See generally Panayides, supra note 6, at 513 (2007) (explaining the role that affirmative obligations play in specialist inventory rebalancing).

292 See Feb. 18, 2011 Panel Report, supra note 146, at 11.

293 See Special Study, supra note 11, at 61-62.

294 Id.

295 Bessembinder et al., supra note 39, at 37-40.

296 See Mao \& Pagano, supra note 3, at 52 (illustrating the difference between intermediated [those with market-makers such as exchanges] and non intermediated markets [such as ATSs, where high-frequency trades occur most frequently]).

297 Letter from R T Leuchtkafer to the Sec. \& Exch. Comm'n, Responding to the Commission's Concept Release on Equity Market Structure (May 6, 2010), available at http://www.sec.gov/comments/s7-02-10/s70210-107.htm.

298 See Patterson \& Rogow, supra note 175.

299 Bhupathi, supra note 5, at 392. 
province of exchanges. This is no longer the case. When a high frequency trader's computer senses uncertainty in the market, the program automatically re-calibrates the trading parameters that it uses to determine whether to buy or sell a given stock and then executes its trades based on that new calibration. ${ }^{300}$ This recalibration can lead to a huge sell-off of stock. ${ }^{301}$ This stock dump then artificially depresses the price of the stock, which leads to even more pricing volatility. ${ }^{302}$ In the days of manual exchange-based trading, the specialist post was one of the primary tools that exchanges used to dampened volatility. ${ }^{303}$ Today, the specialists no longer wield the power that they once did.

The other tool that exchanges relied on to dampen volatility was the "circuit breaker.", Average ("The Dow") lost and then regained more than 900 points in the course of just a few minutes. ${ }^{305}$ This event (hereinafter the "FlashCrash") was the largest ever intraday loss on the Dow. "The FlashCrash was the first large scale public display of the potential dangers that have come to exist since the trading volume shift from exchange based trading to high frequency trading. ${ }^{307}$ The massive pricing swing that occurred during the Flash-Crash activated the circuit breakers in place at the NYSE and other exchanges, but elsewhere, in the automated systems of high frequency traders, some of the algorithm based systems continued to push prices into the ground. ${ }^{308}$ Other high fre-

300 Id.

301 See generally FLASH-CRASH REPORT, supra note 54 (chronicling the events of May 6, 2011 and discussing the circumstances that accidently propelled the U.S. stock markets into a free-fall; a free-fall that was is no way connected to market fundamentals).

302 Bhupathi, supra note 5, at 392.

303 See Mao \& Pagano, supra note 3, at 52.

304 THE N.Y. STOCK EXCH., THE NEW York StOck EXCHANGE: THE FIRST 200 YeARS 202 (James E. Buck ed., 1992). Circuit breakers were originally put into place to ensure that the exchanges would not miss orders because of extreme peaks of volatility. Id. Even the most skilled trader could only handle a certain number of orders at a time. Id. With the introduction of automated order routing in the 1970s, physical trading capacities ceased to be a problem, but circuit breakers remained because they also served an important price-dampening feature. $I d$. Circuit breakers helped curb volatility and allowed the markets to absorb information. Id. These circuit breakers were automatic trading pauses that took effect when stocks lost more than a certain percentage of their value in a short period of time. Id. The idea was not to prevent a stock from losing value if it was indeed less valuable, rather the purpose of circuit breakers was to allow the markets a pause so that participants could assimilate information and proceed accordingly. Id.

305 Alexandra Twin, Glitches Send Dow on a Wild Ride, CNN MonEy (May 6, 2010, 7:36 PM), http://money.cnn.com/2010/05/06/markets/markets_newyork/.

306 Id.

307 Chilton, supra note 150.

308 FLASH-CRASH REPORT, supra note 54, at 6 ("Another key lesson from May 6 is that many market participants employ their own versions of a trading pause - either generally or in particular products - based on different combinations of market signals. While the withdrawal of a single participant may not significantly impact the entire market, a liquidity crisis can develop 
quency trading systems simply withdrew their bids and offers from the marketplace. ${ }^{309}$ In years past, circuit breakers at the NYSE would have likely been enough to prevent the day's losses (or at least greatly stem the hemorrhaging), but because the NYSE no longer maintains a majority market share, the NYSE's own procedures for halting trading only impacted a small fraction of the overall markets. This is not an argument in favor of the monopoly that was the NYSE; rather, it is an illustration of the dangers of a fragmented market without any one entity in control. The SEC should in theory be that entity, but until the Commission starts acting with uniformity regarding safety procedures, events like the Flash-Crash will likely continue.

As a result of the Flash-Crash and subsequent findings, the SEC began to implement trading "pauses." were implemented on a provisional basis. ${ }^{311}$ Thus far the trading pauses have worked very well. This is a prime example of the SEC's successful implementation of a tool that was previously used only by exchanges, but it isn't enough. The SEC is further exploring how to improve the structure of the pause system so that it functions at the highest level of efficiency. ${ }^{312}$ In the interim, the Commission should take as many of the exchanges' old systems as are still applicable and implement them.

The SEC's mission is "to protect investors, maintain fair, orderly, and efficient markets, and facilitate capital formation.," the argument of whether the very concept of high frequency trading is at odds with the purpose of equity markets, or just the natural next step in an ever-evolving market, the plain fact is that based on size alone, high frequency traders have the potential to create extreme market volatility. As exchanges lost market share, they also lost the ability to enforce the rules that they had developed. As selfregulatory organizations, the exchanges were the primary defenders of the capital markets. Exchanges had market-makers (in the form of specialists) to ensure liquidity. ${ }^{314}$ As the volume shifted to high frequency traders, the responsibility for ensuring liquidity and avoiding

if many market participants withdraw at the same time. This, in turn, can lead to the breakdown of a fair and orderly price-discovery process, and in the extreme case trades can be executed at stub-quotes used by market makers to fulfill their continuous two-sided quoting obligations.”).

309 Feb. 18, 2011 Panel Report, supra note 146, at 3.

310 Rule Changes Relating to Trading Pauses Due to Extraordinary Market Volatility, Exchange Act Release No. 34-6225, 2010 SEC LEXIS 1835, at*7 (June 10, 2010).

311 Id. at $* 9$.

312 See Feb. 18, 2011 Panel Report, supra note 146, at 6.

313 See supra note 64 and accompanying text.

314 Anand \& Weaver, supra note 289, at 102. 
dangerous volatility spikes, shifted directly to the SEC. ${ }^{315}$ The SEC's recent adoption of trading pauses in all but the least active stocks, is a step toward the future, but if high frequency traders are here to stay, the SEC needs to make sure that they learn from the lessons learned from the history of the exchanges. Incentives alone are not enough to protect U.S. equity markets from artificial volatility and liquidity crises. This is not new information. The reaction of the Nasdaq marketmakers during the 1987 crash put legislators on notice that incentives alone weren't enough — that was twenty-five years ago

\section{B. Re-defining What it Means To Be a Market-maker: Mandatory Uniform Affirmative Obligations for Market-makers}

In order to impose affirmative obligations on de facto liquidity providers, the SEC must begin by re-defining the term market-maker; focusing the new definition on which activities obligate a market participant to act as a market-maker, and by laying out what a designation as a market-maker means for a market participant's trading actions. The current definition of a market-maker has not been updated since $1993{ }^{316}$ High frequency traders are today's de facto liquidity providers. $^{317}$ They are informal market-makers in a time when formal market-makers are no more. Given this very real and current problem, the SEC needs to change the rules. When high frequency traders act as market-makers they should be held accountable as such.

The Commodity Futures Trading Commission, ("CFTC") (in accordance with Dodd-Frank regulations) is in the process of enacting new "position limits.", In the CFTC context, position limits are:

limits on the amounts of trading which may be done or positions which may be held by any person under contracts of sale of such commodity for future delivery on or subject to the rules of any contract market or derivatives transaction execution facility, or on an electronic trading facility with respect to a significant pricediscovery contract, as the Commission finds are necessary to diminish, eliminate, or prevent such [a] burden [on interstate commerce].

315 See supra note 219 and accompanying text.

316 Securities and Exchanges, Definitions and Application, 15 U.S.C.A. § 78c (38) (1993).

317 See Letter from Charles Schumer, U.S. Sen., to Mary Schaprio, SEC Comm'r (July 27, 2009), available at http://schumer.senate.gov/new_website/record.cfm?id=316252.

318 See Silla Brush, CFTC'S Chilton Urges Position Limits, High-Frequency Trade Curbs, BloOMBERG (Dec. 10, 2010, 12:13PM), http://www.bloomberg.com/news/2010-12-08/cftc-schilton-urges-position-limits-high-frequency-trade-curbs.html.

319 Excessive Speculation, 7 U.S.C.A. § 6a (1) (West 2010); Commodity Exchange Act, § 4a (a) (1936) (current version at 7 U.S.C. $§ 2 \mathrm{a}(2000)$ ) (pointing out that the CFTC has always had 
The SEC could and should impose similar position limits for high frequency traders who participate in market-making activities. The concern is not speculative profit making. There have always been speculators in markets. ${ }^{320}$ Speculators are a vital part of market activities. ${ }^{321}$ Markets need people who are willing to take a risk that something will go up (or down) in value; it is fundamental to the economic principles of supply and demand. ${ }^{322}$ The true concern with the current equity market structure is that increased concentration of speculative activities creates danger to other market participants. CFTC Commissioner Chilton succinctly explained this difficulty in a December 2010 speech to High Frequency Trading World:

there is nothing whatsoever wrong with those speculators being in markets. Bless them. We need speculators. Without them, there is no market. The sheer size..of concentrated speculative interests has the potential of moving markets, of influencing true price-discovery. That can make life difficult for the hedgers who use markets to manage commercial business risks, and for consumers who rely upon them to fairly price just about everything they purchase. Everything from a loaf of bread to a gallon of milk or gas to a home mortgage is impacted by these markets. ${ }^{323}$

The main purpose of the creation of a national market system was to facilitate competition and free market principles. ${ }^{324}$ This new concentration of activity violates the national market system idea. Furthermore, under the pre-NMS paradigm, the existing centralized market system had protections in place. Now the equity markets are faced with a similar centralization of activity, but without any of the rigorous rules and restrictions that existed under the NYSE/Nasdaq duopoly.

the power to enact position limits; and that these latest position limits simply address new concerns).

320 See MEEKER, supra note 69, at 75 (using the term speculator interchangeabley with the term investor, thus indicating that speculators were a fundamental element of U.S. equity markets as early as 1922 when Meeker published the work).

321 Francesco Guerrera, CME Chairman Rebuffs Obama on Speculators, WALL STREET JOURNAL (May 2, 2012, 1:29PM), http://online.wsj.com/article/SB1000142405270230387760 4577379992435623130.html (reporting on CME Chairman, Terry Duffy's explanation of the vital role of spectators in capital markets).

322 Chilton, supra note 150.

323 Id.

324 See Jesse Westbrook, SEC Considers Rules for High-Frequency Traders After Plunge, BLOOMBERG (Sept. 7, 2010, 3:01PM), http://www.bloomberg.com/news/2010-09-07/sec-weighsnew-rules-for-high-frequency-traders-after-may-6-market-plunge.html. 
The SEC needs to examine and re-define what the term marketmaker means in the context of equity market participation. According to the SEC definition, the term market-maker means

any specialist permitted to act as a dealer, any dealer acting in the capacity of block positioner, and any dealer who, with respect to a security, holds himself out (by entering quotations in an inter-dealer communications system or otherwise) as being willing to buy and sell such security for his own account on a regular or continuous basis.

This definition is extremely outdated. It was written at a time when specialists were the predominant market-makers. ${ }^{326}$ The definition of a market-maker should be updated to include any trader who: provides the appearance of liquidity to the market because of the volume of trades transacted; or who holds himself out as willing to buy and sell a security for his own account on a regular or continuous basis.

The age of the specialist as a meaningful liquidity provider is over. $^{327}$ The SEC needs to recognize that the entities that currently hold themselves out as market-makers are no more obligated to make markets than any ordinary broker would be. High frequency traders have all of the benefits without any real responsibility or accountability. As previously recommended one possible way to remedy this problematic situation is to impose intraday position limits on high frequency traders acting as de facto market-makers. Traders who surpass the position limitations would be required to register as marketmakers. In turn, registered market-makers would be required to act as obligated market-makers by providing contra-side liquidity during specified times. $^{328}$ A regulation of this sort would help to ensure liquidity during times of crisis by forcing the market participants who transact the most volume to remain accountable to the market that they utilize regardless of whether the participant is an exchange-based trader, a broker-dealer, or a high-frequency trader. By basing the definition of a market-maker on the volume of the entity's trading activities, the SEC will not have to constantly reevaluate the definitions of each different kind of market participant. Furthermore, the

\footnotetext{
325 Securities Exchange Act of 1934, § 3(a)(38).

326 See Commodity Exchange Act, supra note 319; see also Simon \& Trkla, supra note 11, at 248-49.

327 See Mehta, supra note 25.

328 Bhupathi, supra note 5, at 392. High frequency traders generally close out the day with no overnight position. In order to be meaningful any position limitations would have to be intraday. Id.
} 
problem of defining, and maintaining a definition of, "high frequency trading" would disappear. Creating a framework that focuses on market activities tied to obligations seals off the loopholes inherent in an entity-definition based system. If Congress went further and added rules and regulations delineating how legal business relationships between affiliated organizations should be managed, for purposes of calculating whether an entity has reached its intra-day position limit, another loophole would be closed.

High Frequency trading also presents the problem of increased message traffic and market surveillance costs. ${ }^{329}$ This, too, is an area where the individuals producing the most amount of market noise should be held accountable. It is not fair to make the market as a whole pay for what is in essence, a tool in the arsenal of the high frequency trader. One of the strategies that high frequency traders use is the rapid placing and cancelling of orders in the marketplace. ${ }^{330}$ This practice, similar if not analogous to the old "flash trades" outcry system, has created some of the aforementioned "market noise costs." High volume, high frequency traders who create informational waste should shoulder the responsibility of paying for the costs associated with that waste. They should also be subject to contra-side liquidity obligations when the volume of their trades exceeds a certain threshold. These instantly cancelled bids and offers have the very real potential to create an illusion of liquidity. Because this type of liquidity could be considered "false liquidity," high frequency traders who conduct significant amounts of this type of trading should be required to ensure the existence of the liquidity that they claim to provide. By requiring market participants that exceed designated volume thresholds to shoulder the related informational costs, the SEC would create an incentive for high frequency traders to build their algorithmic programs around completed stock purchases, which would help deter trading programs that are built around false liquidity.

Affirmative obligations can take a number of forms, but the most common affirmative obligation is the requirement that a marketmaker maintain a "fair and orderly market" by using the funds in his account to ease temporary imbalances in the supply or demand of a given stock, thereby increasing liquidity and decreasing volatility.

329 Feb. 18, 2011 Panel Report, supra note 146, at 11.

330 Equity Market Structure Concept Release, supra note 24, at 3599 (mentioning the practice of flash-trading).

331 See Bhupathi, supra note 5, at 387.

332 See Westbrook, supra note 324.

333 Feb. 18, 2011 Panel Report, supra note 146, at 11.

334 Equity Market Structure Concept Release, supra note 24, at n.70. 
Part and parcel with this requirement that market-makers provide contra-side liquidity are the guidelines for how a market-maker should go about the business of making a market. Thus far the SEC has never imposed regulations that specify how a market-maker has to go about fulfilling his trading duties. ${ }^{335}$ When the SEC first addressed the issue of market-makers, it drafted a simple regulation because the primary regulatory body in U.S. equity market then was the NYSE's SRO branch. ${ }^{336}$ The SEC did not need to get involved with how the exchanges and venues made markets because for the most part, there was nothing for them to comment or improve upon. The SEC allowed each individual exchange to set up specific rules that governed the limitations and requirements for their specialists. ${ }^{337}$ The SEC only required that exchanges which chose to employ specialists had to inform the SEC.

Now that the days of exchange-specialists-as-market-makers are essentially over, and the $\mathrm{SRO}$ responsibilities that once belonged to the exchanges now belong to the SEC (carried out through the quasigovernmental subsidiary, FINRA), the SEC needs to change its level of involvement with market-makers and market-making activities. In light of the shift from exchange traded volume to high frequency traded volume, created by automated systems, the SEC needs to readdress how market-makers make markets. Exactly how to implement such a system is a topic that will undoubtedly require further investigation; however, the primary issues to consider are: how much volume a given venue produces and how many unique stocks the venue trades. In short, the SEC needs to establish a regulatory infrastructure for a marketplace that is now dominated by automated trading.

\section{Incentives for Willing Participants}

In addition to imposing mandatory contra-side liquidity obligations on market participants who transact average daily volumes in excess of the previously suggested position limitations, there are incentive based reasons why a market participant might want to voluntarily take on market-maker obligations. ${ }^{339}$ The SEC has entertained implementing various programs and policy changes designed to entice high frequency traders to voluntarily take on the role left vacant by

335 Regulation of Specialists, 17 C.F.R. § 240.11b-1; 15 U.S.C. $§ 78 k$ (b) (2000); Simon \& Trkla, supra note 11, at 357-84.

336 See Simon \& Trkla, supra note 11, at 222-23.

337 Id.

338 Regulation of Specialists, 17 C.F.R. $§ 240.11 b-1 ; 15$ U.S.C. $§ 78 k(b)$ (2000).

339 See Banner, supra note 58. 
the mass exodus of specialists. Some of these proposals include: changes to the structure of the maker/taker trading model, ${ }^{340}$ peak load pricing strategies, ${ }^{341}$ an expansion of information dissemination that would pave the way for high frequency traders to take advantage of the vast computing resources at their fingertips, ${ }^{342}$ differential pricing, ${ }^{343}$ and preferential co-location provisions. ${ }^{344}$

The goal of nearly all of these policy initiatives is to create a market structure wherein market participants in general and high frequency traders in particular, are able to take advantage of the information available as a result of the introduction of super computers. In much the same way that specialists once maintained a special advantage and corresponding obligations because of their location on the floor, the SEC should now seek to create an analogous system for the modern world. It was after all, the intent of the original NMS mandate to create a more transparent and accessible equity marketplace. ${ }^{34}$ This optional incentive based system is an effective part of a much needed larger reform plan-a plan with the end goal of ensuring that the most active of traders being given the least amount of flexibility in their market choices, because those traders literally have the ability to move markets. While incentive based programs and policy changes are insufficient to protect the economy from market participants who can independently move markets, the value of these programs should not to be overlooked. Incentive based programs are a great way to entice middle volume traders into the market as accountable trading participants. $^{346}$

The question of how to protect the American economy from the rapid changes that have occurred in the structure of equity markets during the last twenty years is an infinitely complex problem. It should be addressed in descending order of importance. The participants that pose the most danger must be dealt with first and must be regulated most stringently. It is for these reasons that the entities with the most power should be subject to official mandatory obligations. A more flexible system can be imposed on parties that are not as powerful as their more active counterparts. It should also be noted that a system which has come apart practically overnight, due to the ever-

340 Feb. 18, 2011 Panel Report, supra note 146, at 9.

341 Id.

342 Id.

343 Id. at 10.

344 Id.

345 See Regulation NMS Adopting Release, Exchange Act Release No. 34-51808, 70 Fed. Reg. 37496 (June 29, 2005).

346 See Feb. 18, 2011 Panel Report, supra note 146, at 10. 
increasing rate of change to the underlying structural systems, must be re-built on a platform of flexibility to allow for future changes. To lose sight of that lesson would be to make a mockery of the people who once dedicated their careers, and in some cases their lives, to ensuring this country's financial stability.

There seems to be consensus at the SEC that some combination of incentives and regulations are required in order to provide a stable and liquid market moving forward. ${ }^{347}$ Assuming the SEC begins addressing the issue by focusing on the market participants with the most power, this appears to be a valid approach to solving some of the problems facing twenty-first century equity market structure.

\section{Moving in the Right Direction}

The SEC has already started to re-examine equity market structure and high frequency trading. ${ }^{348}$ The May 6, 2010, Flash-Crash was a very real example of the clash between the old and the new world orders, and what can happen when technology moves faster than regulation in vital marketplaces. ${ }^{349}$ As a result of the Flash-Crash, the SEC implemented new rules for market-makers that essentially banned the use of "placeholder" bids and offers. ${ }^{350}$ These placeholders, commonly referred to as stub-quotes, ${ }^{351}$ were once upon a time, a way for marketmakers to nominally comply with their quoting obligations. ${ }^{352}$ In the present market, stub-quotes have little value. The parties that necessitated the existence of stub-quotes have long since left the floor, but to leave stub-quotes as a part of the infrastructure is equivalent to leaving power-tools at an abandoned construction site. ${ }^{353}$ It is foolish and unnecessary. The SEC has also put circuit breakers in place in order to pause trading in situations when the computer algorithms that run high frequency trading systems react to erroneous market changes

347 See id.

348 See Interview by Tess Vigeland with Mary Schapiro, Chairman, SEC (May 5, 2011), available at http://www.marketplace.org/topics/business/flash-crash/how-wall-street-has-changedflash-crash.

349 FLASH-CRASH REPORT, supra note 54, at 2 ("On May 6, 2010, the prices of many U.S.based equity products experienced an extraordinarily rapid decline and recovery. That afternoon, major equity indices in both the futures and securities markets, each already down over $4 \%$ from their prior-day close, suddenly plummeted a further 5-6\% in a matter of minutes before rebounding almost as quickly.").

350 See To Enhance Quotation Standards for Market-makers, Exchange Act Release No. 34-63255, 2010 WL 4466998 (Nov. 5, 2010) (detailing the elimination of place-holder bids and offers, effectively eliminating the practice of flash trading).

\footnotetext{
351 Id.

352 See Mehta, supra note 25.

353 Mehta, supra note 25.
} 
before human beings can intervene. ${ }^{354}$ These are both steps in the right direction, but they are not enough. The naked concentration of power that has gathered around high frequency traders must be regulated. To fail to regulate entities that can literally move markets, to the detriment of both institutional investors and farmers alike, is to fail the people that the Exchange Acts were created to protect.

\section{CONCLUSION}

The role served by traditional market-makers was all but abolished by Regulations ATS and NMS. High frequency traders have replaced the liquidity function once provided by market-making specialists. High frequency traders claim to provide liquidity in the market. In practice, they only provide liquidity when the algorithms that they employ determine that the risk reward ratio is tipped in their favor. They have no obligation to continue to provide liquidity during periods of economic turmoil, as exchange-based specialists once did. Specialists were given a right to trade in a certain way because they also agreed to take on the duty of standing ready to take the other side of the trade when there was a lack of liquidity. When that promise failed to protect the markets, the SEC intervened and imposed mandatory affirmative obligations on exchanges choosing to employ specialists. High frequency traders now maintain a similar benefit without the obligation.

The equity market is one of the core pillars of the global economy. The national market system was designed to help the equity markets, not harm them. Market quality should not suffer because of technology and increased competition; market quality should be improved by the introduction of these elements. For market-quality to be harmed by advancement is contrary to the entire objective of the national market system. Competition is good but not at the expense of the quality and integrity of the equity market system.

Some argue that the cost of requiring high frequency traders to comply with quote obligations is not fair to the traders, but assuming that protections limiting the losses of quote obligators are in place for unexpected market events, the burden for those with the highest level of market participation is minimal. High frequency traders make huge sums of money from extremely short-term transactions. The SEC has made it clear that when the interests of long-term investors and the interests of short-term traders' conflict, the interests of the

354 Rule Changes Relating to Trading Pauses Due to Extraordinary Market Volatility, Exchange Act Release No. 34-6225, 2010 SEC LEXIS 1835, at*14-15 (June 10, 2010). 
long-term investor should prevail. ${ }^{355}$ In this situation, the cost to the short-term trader is less important than protecting the interests of the long-term investor. 